San Jose State University

SJSU ScholarWorks

Master's Theses

Master's Theses and Graduate Research

1989

\title{
Effect of an intron from a dicotelydenous plant on transient gene expression in carrot and maize protoplasts
}

Nicole Helen Cooper

San Jose State University

Follow this and additional works at: https://scholarworks.sjsu.edu/etd_theses

\section{Recommended Citation}

Cooper, Nicole Helen, "Effect of an intron from a dicotelydenous plant on transient gene expression in carrot and maize protoplasts" (1989). Master's Theses. 3062.

DOI: https://doi.org/10.31979/etd.abbd-j7wn

https://scholarworks.sjsu.edu/etd_theses/3062

This Thesis is brought to you for free and open access by the Master's Theses and Graduate Research at SJSU ScholarWorks. It has been accepted for inclusion in Master's Theses by an authorized administrator of SJSU ScholarWorks. For more information, please contact scholarworks@sjsu.edu. 


\section{INFORMATION TO USERS}

The most advanced technology has been used to photograph and reproduce this manuscript from the microfilm master. UMI films the text directly from the original or copy submitted. Thus, some thesis and dissertation copies are in typewriter face, while others may be from any type of computer printer.

The quality of this reproduction is dependent upon the quality of the copy submitted. Broken or indistinct print, colored or poor quality illustrations and photographs, print bleedthrough, substandard margins, and improper alignment can adversely affect reproduction.

In the unlikely event that the author did not send UMI a complete manuscript and there are missing pages, these will be noted. Also, if unauthorized copyright material had to be removed, a note will indicate the deletion.

Oversize materials (e.g., maps, drawings, charts) are reproduced by sectioning the original, beginning at the upper left-hand corner and continuing from left to right in equal sections with small overlaps. Each original is also photographed in one exposure and is included in reduced form at the back of the book. These are also available as one exposure on a standard $35 \mathrm{~mm}$ slide or as a $17^{\prime \prime} \times 23^{\prime \prime}$ black and white photographic print for an additional charge.

Photographs included in the original manuscript have been reproduced xerographically in this copy. Higher quality $6^{\prime \prime} \times 9^{\prime \prime}$ black and white photographic prints are available for any photographs or illustrations appearing in this copy for an additional charge. Contact UMI directly to order.

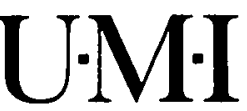

University Microfilms International 
Order Number 1337795

Effect of an intron from a dicotyledonous plant on transient gene expression in carrot and maize protoplasts

Cooper, Nicole Helen, M.A.

San Jose State University, 1989 



\author{
A Thesis \\ Presented to \\ the Faculty of the Department of Biological Sciences \\ San Jose State University \\ In Partial Fulfillment \\ of the Requirements of the Degree \\ Master of Arts
}

\author{
by \\ Nicole Helen Cooper \\ May, 1989
}


APPROVED FOR THE DEPARTMENT OF BIOLOGICAL SCIENCES

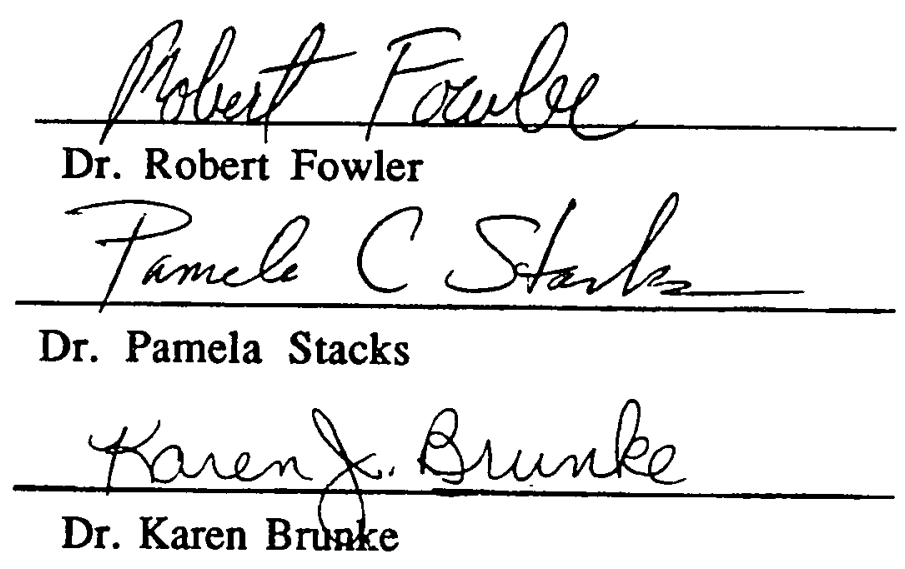

APPROVED FOR THE UNIVERSITY

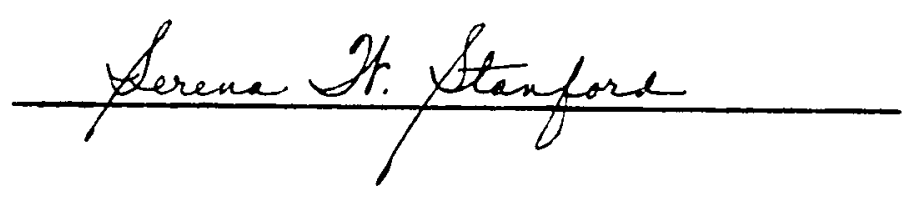




\begin{abstract}
The purpose of this investigation was to determine if an intron isolated from a dicotelydenous plant could enhance gene expression in carrot, a dicot, and maize, a monocot. The intron studied was the first intron from the soybean ribulose 1,5 bisphosphate carboxylase small subunit (rbcS) gene. The expression cassettes contain the $35 \mathrm{~S}$ Cauliflower Mosaic Virus or the Brassica hsp 80 promoter, various intron fragments, the chloramphenicol acetyltransferase gene and the nopaline synthase polyadenylation region. Data show that no expression enhancement occurs when this intron is included in the $5^{\prime}$ untranslated leader sequence of the reporter gene when tested in carrot protoplasts. However, the intron containing constructs enhance gene expression up to 10 fold when tested in maize protoplasts. Reversal of the intron orientation relative to the reporter gene, reduces gene activity below control levels obtained with no intron present. This result suggests that splicing is necessary for the enhancement to occur.
\end{abstract}




\section{Acknowledgements}

This thesis is dedicated to my remarkable family. My parents, Brian and Helen, are the reason that I value education so much. Their constant encouragment throughout my entire life made college graduation and this Master's degree a reality. My sisters were (and still are) a constant source of support and comical relief from my often too serious nature. Thank you all for the family barbeques, fireworks and camping expeditions.

Many thanks to Ralph Sinibaldi, who somehow put an end to my procrastination over writing this thesis and other projects. Without his friendship and concern this project would have been intimidating instead of an exciting challenge.

I also wish to thank my thesis committee; Robert Fowler, Pam Stacks and Karen Brunke. Bob and Pam were a great help in conceptualizing, writing and editing this manuscript. Their friendship and encouragment made being a graduate student very rewarding. Karen and her entire lab at Sandoz not only taught me how to succeed in a molecular biology laboratory, but how to become great friends with the people I worked with. Special thanks for the summer volleyball games, lunches and dinners where we always "talked science"! 


\title{
Table of Contents
}

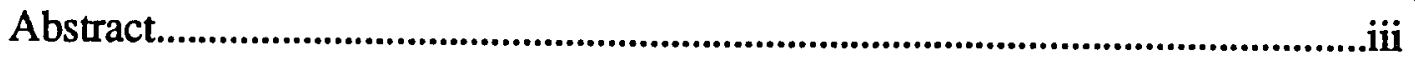

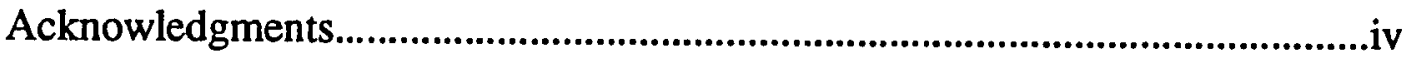

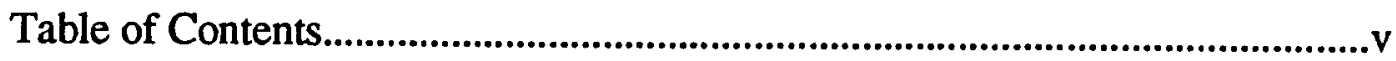

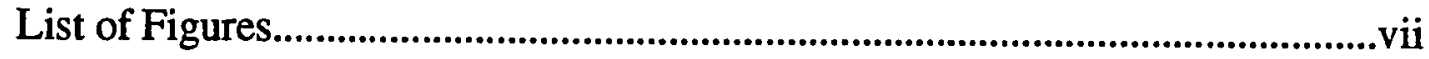

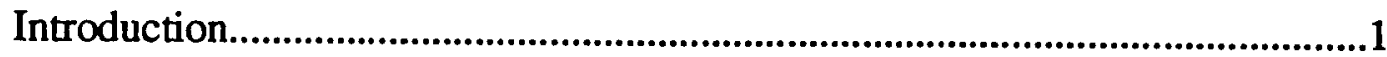

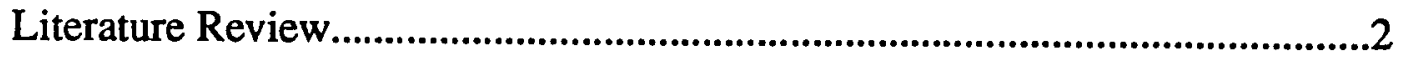

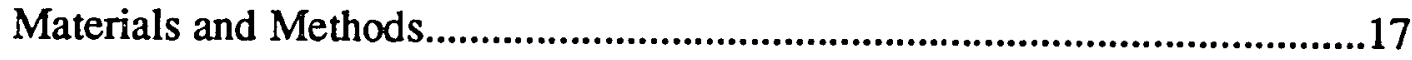

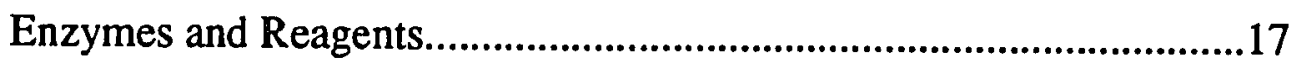

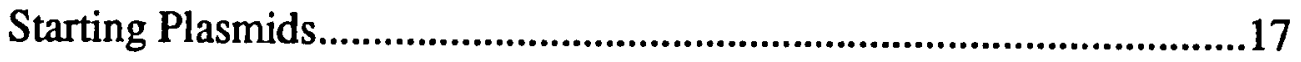

Preparation of Competent E, coli JM83....................................17

Small Scale Isolation of Plasmid DNA..........................................18

Large Scale Isolation of Plasmid DNA.........................................18

Agarose Gel Electrophoresis.......................................................19

Ligation and Transformation.......................................................19

Construction of Promoter Cassettes...............................................19

Construction of Intron Inserts in Promoter Cassettes.............21

Bacterial Freezer Stocks.....................................................................21

Carrot and Maize Cell Line Maintenance.....................................23

Protoplast Production........................................................................23

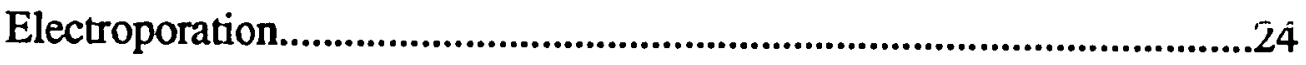

Transient Chloramphenicol Acetyltransferase Assays..........24

HPLC Analysis of Transient CAT Activity..................................26 
Table of Contents (continued)

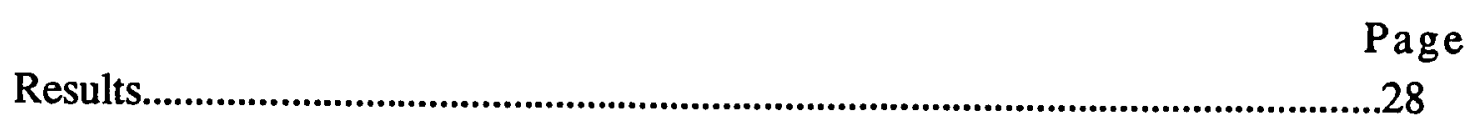

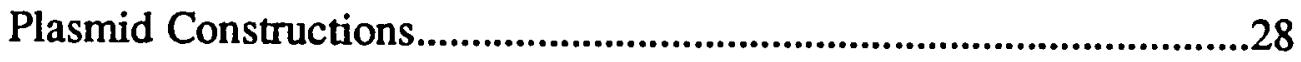

Transient Assay Results from Carrot Protoplasts.....................32

Transient Assay Results from Maize Protoplasts......................39

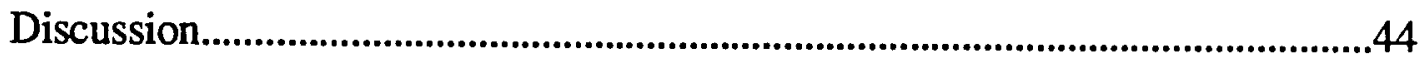

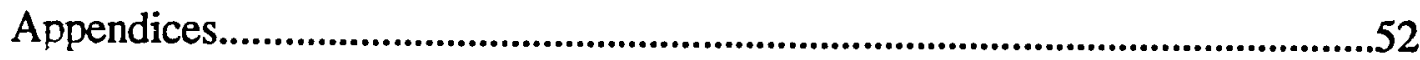

Literature Cited.............................................................................................58 


\section{List of Figures}

Page

1. Mechanism of nuclear pre-mRNA splicing....................................8

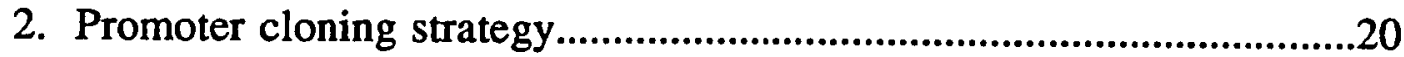

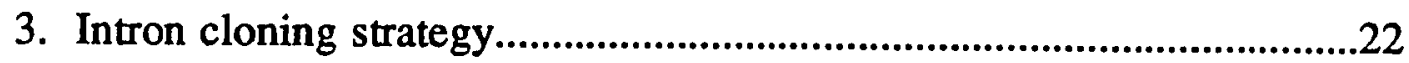

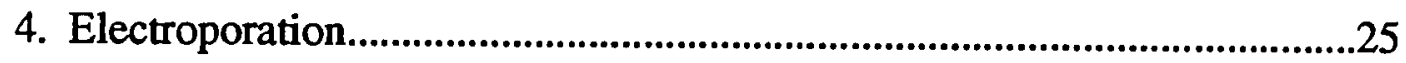

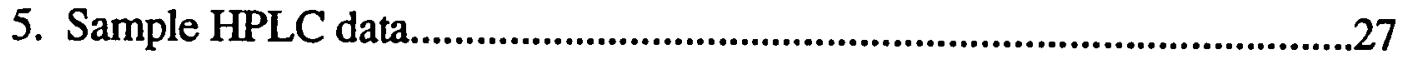

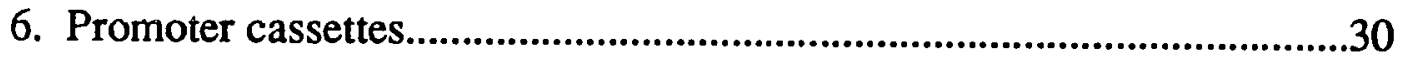

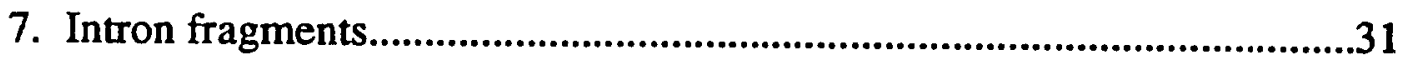

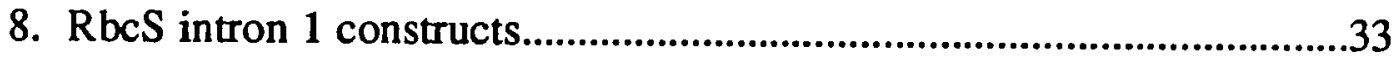

9. BamHI digest of intron containing plasmids...............................34

10. RsaI digest of intron containing plasmids...................................36

11. Relative CAT activity in carrot protoplasts...................................38

12. Graph of relative CAT activity of pZO219 derivatives in carrot protoplasts.....................................................40

13. Relative CAT activity in maize protoplasts..................................41

14. Graph of relative CAT activity of pZO219 derivatives in maize.protoplasts 


\section{List of Appendices}

1. Splice site and branch point consensus sequences.....................52

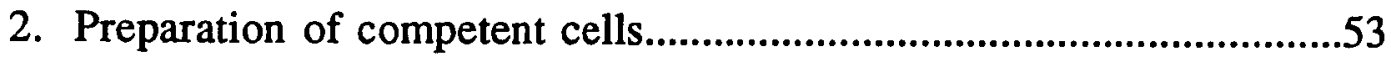

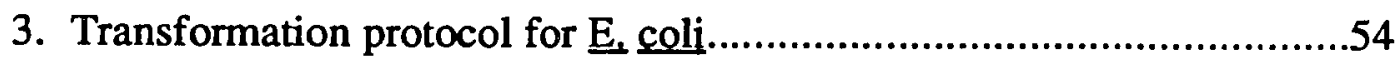

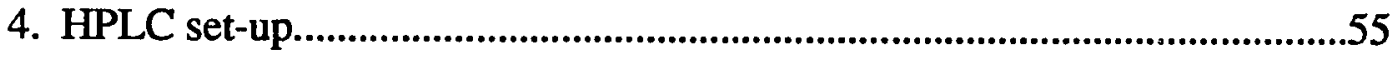

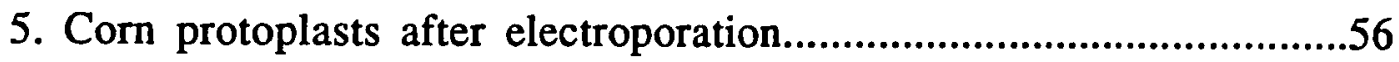




\section{Introduction}

Introns are usually non-coding regions, interspersed within the coding regions of the DNA and pre-mRNA of eukaryotic genes. The processing of pre-mRNA involves the cleavage of introns and the ligation of the processed pre-mRNA to yield mature mRNA transcripts. In plants and animals, specific sequences at both intron/exon borders and an internal branch point are recognized by small nuclear ribonucleoproteins (snRNPs). The snRNPs facilitate the formation of a lariat-like intron structure which is subsequently spliced out of the transcript. Most plant genes contain introns and require correct splicing for normal gene expression. Thus, the splicing of an intron represents a potential point at which gene expression could be regulated.

The objective of this study was to examine the effect of an intron isolated from a dicotelydenous (dicot) plant on transient gene expression in carrot, (dicot) and maize, (monocot) cells. Constructs contained the Cauliflower Mosaic Virus $35 \mathrm{~S}$ (CaMV 35S) promoter or a Brassica heat shock promoter, the chlorampheriicol acetyltransferase (CAT) gene and the nopaline synthase (Nos) polyadenylation region. The first intron from soybean ribulose-1,5bisphosphate carboxylase/oxygenase small subunit (rbcS) gene was inserted into the $5^{\prime}$ untranslated portion of the plasmid, between the promoter and the CAT gene. These plasmids were then introduced into carrot and maize protoplasts by electroporation. The efficiency with which the carrot and maize cells transcribed and processed the pre-mRNA derived from the DNA clones was measured by the amount of detectable CAT gene expression. From data generated by the transient gene expression assays, some general conclusions were made regarding the effect of an intron in a monocot and dicot system. 


\section{Literature Review}

Within the last decade or so, our understanding of eukaryotic gene organization has grown tremendously. We have found that the coding sequences of many genes are interrupted by non-coding regions, known as introns (Abelson, 1979; Padgett et al., 1986). The term "intron" was proposed by Gilbert (1978), meaning the region between or interrupting exons.

Originally, coding regions of genes were envisioned as cistrons, in which one gene or functional unit corresponded to one polypeptide chain. Upon the discovery of introns (Berget et al., 1977; Chow et al., 1977; Klessig, 1977), our previous notion of gene cistronic organization was modified to the idea of a transcriptional unit, interrupted by non-coding sequences which were subsequently removed from the heterogeneous nuclear RNA (hnRNA), thus yielding a shorter mature RNA. This intron-containing model of gene organization accounts for some of the huge excess of DNA, above what is required to code for known proteins, in eukaryotic organisms (Britten and Davidson 1969). Introns also help account for the length differences between hnRNA and cytoplasmic mRNA observed by Darnell (1976).

Introns are usually non-coding regions interspersed within the coding region of genes. The length of introns varies tremendously, from 30 (Ghosh et al., 1978) to 60,000 (Scott et al., 1983; Schnuewly et al., 1986) nucleotides. In each instance, the removal of the intron from the immature transcript, known as splicing, may be required for transcript stability and subsequent gene expression. Abnormal intron splicing may lead to aberrant protein production or a total loss of protein expression (Hamer and Leder, 1979b; Gruss et al., 1979).

\section{Intron Origin and Position Conservation}

The discovery of introns and the need for intron processing led to two conflicting theories of intron origin. One hypothesis (Doolittle, 
1978) proposes that introns and the required splicing mechanisms were present in primitive cells, retained by eukaryotes and subsequently were lost in prokaryotes due to evolutionary pressure for rapid replication. Another hypothesis (Orgel and Crick, 1980) depicted introns as arising by insertion of transposable elements into ancestral prokaryote-like genes. Along with the insertion of those new elements was the obligatory development or acquisition of the splicing mechanisms within the developing "eukaryotic cell."

Evidence in a review by Gilbert et al. (1986) strongly supports the first hypothesis. If it were true that introns were present in "primitive" genes required by primordial cells (i.e. metabolic genes), then developing eukaryotes would have retained the introns while the quickly replicating prokaryotes would have lost the introns from those same genes. In Gilbert's review, he presented evidence of that phenomena. He demonstrated that the intron position (not sequence) within comparable genes was conserved in many organisms. By comparing intron position and evolutionary divergence of prokaryotes to eukaryotes, fungi to primitive animals and plants, and even the divergence from a primitive "plant" to monocot and dicot species, Marchionni and Gilbert (1986) showed that the triosephosphate isomerase (TIM) gene and the intron positions within that gene were highly conserved in most cases. They proposed that the lack of some of the TIM introns in prokaryotes was a better explanation of the conserved position nature of introns than the addition of those introns into the appropriate genome site of eukaryotic genes. Similarly, Quigley et al. (1988) showed intron position conservation within the glyceraldehye-3-phosphate dehydrogenase (GADPH) gene between maize chloroplast GADPH and thermophilic eubacterial GADPH's. There is one clear case of intron loss (Perler and Estratiadis, 1980) but there is yet no proof of intron addition.

Marchionni's study of the TIM gene was the first demonstrated case of intron conservation between plants and animals. Shah et al. (1983) compared the actin gene over the same range of organisms, 
and also found intron conservation. The study icvealed that one intron position out of three in plants and one out of seven in rat, was identical. This difference was also attributed to loss of introns during evolution. He demonstrated that within plants, the position of three actin gene introns were highly conserved. The first intron position in maize and soybean also corresponded to an intron position in a nematode actin gene. These comparisons of intron positions demonstrated not only the great evolutionary distance between prokaryotes, animals and plants, but also the great similarities within plant groups.

A similar comparison of intron position in conserved genes between monocots and dicots, supported the notion of a relatively close relationship between these two groups of plants. The conservation of intron position was demonstrated between monocot and dicot plant species by Chang and Meyerowitz (1986). They showed that the position of six out of nine alcohol dehydrogenase (Adh1) introns were conserved between Arabidopsis and maize. The lack of three Adh1 introns in Arabidopsis could also be attributed to intron loss, corresponding to the small genome size of that species. Ribulose-1,5-bisphosphate carboxylase/oxygenase small subunit (rbcS), another gene which was highly conserved in photosynthetic plants, showed extensive position conservation of the first intron between the monocot and dicot species studied. According to Nagy et al. (1986), the rbcS intron 1 was in the same position in the following species; Nicotiana plumbagini, N, tabacum, soybean, pea, Solanum tuberosum (Wolter et al., 1988) and wheat (Broglie et al., 1983). LeBrun et al. (1987) also reported the same intron position in maize. The rbcS intron 2, also present in all dicot species, was not present in any monocot species thus far examined. RbcS genes from Solanaceas contain a third intron which was not reported in any other plant family (Wolter et al., 1988). The conserved nature of the rbcS intron 1 made it a good choice for comparison of intron effects in monocots and dicots. The relative position of the rbcS intron 1 and other introns, between monocots and dicots, suggested similar intron 
processing machinery. However, that apparent similarity does not hold true under close scrutiny.

Intron Types and Examples

There are four major classes of introns, each with a particular splicing mechanism. The classes are; 1) nuclear pre-tRNA introns, 2) group 1 introns, 3) group 2 introns, and 4) nuclear pre-mRNA.

Following is a brief review of the first three intron types and a more detailed discussion of the last class, nuclear pre-mRNA.

Nuclear pre-tRNA intron splicing is well understood in Saccharomyces cerevisiae (van der Veen et al., 1986; 1987a; 1987b; Jarrell et al., 1988; Siliciano and Guthrie, 1988). Several yeast nuclear pre-tRNA's contain a single short intron located 1 nucleotide $3^{\prime}$ of the anticodon (Sprinzl et al., 1987). No sequence or length conservation or recognizable splice signals have been observed. The splicing of this type of intron involves two steps (Peebles et al., 1983). First, the 5' and $3^{\prime}$ intron borders are cut by a nuclear membrane derived endonuclease, releasing a linear intron fragment. The second step is the ATP dependent religation of the flanking exons by RNA ligase, another nuclear membrane derived protein. Higher eukaryotic pretRNA undergoes a slightly different processing pathway (Lasky et al., 1983).

The splicing of transcripts containing group 1 introns was first studied in Tetrahymena $26 \mathrm{~S}$ pre-rRNA. Requirements for in vitro splicing of these introns are minimal, only magnesium and guanosine (Cech et al., 1981; Kruger et al., 1982). Several short sequences are common to all group 1 introns (Burke et al., 1987). The secondary structure created by these sequences are very important in the splicing mechanism. The actual splicing event involves the cleavage of the $5^{\prime}$ exon by transesterification, leaving the intron and $3^{\prime}$ exon still attached. A second transesterification reaction occurs which joins the two exons and concomitantly releases the intron fragment. In some cases, the intron fragment can circularize (Cech and Bass, 
1986). Although the autocatalytic properties of group 1 introns are presumably encoded in the conserved sequences, not all group 1 introns can be spliced in vitro (Garriga et al., 1984).

Group 2 introns are found in some pre-mRNA's of fungal (Davies et al., 1982; Michel et al., 1982) and plant mitochondria and some chloroplast pre-tRNA's (van der Veen et al., 1987a). This group of introns is characterized by a $5^{\prime}$ and $3^{\prime}$ consensus sequence (Keller and Michel, 1985; Cech, 1983) and 6 putative hairpin structures (Michel and Dujon, 1983). Group 2 introns can also be excised autocatalytically, but with a substantially different mechanism from group 1 introns (van der Veen et al., 1986). In vitro excision can occur with the addition of magnesium and spermidine, no guanosine is required. A lariat structure is generated by transesterification of the $5^{\prime}$ splice site and the branch point near the $3^{\prime}$ splice site. The exons are then ligated, releasing a lariat shaped intron. The specificity and catalytic nature of this splice mechanism are at least partially dependent on the primary and secondary structure of these introns (Schmeizer and Schweyen, 1986). This lariat formation is also an observed splice intermediate in the processing of nuclear premRNA's.

Nuclear Pre-mRNA

Splicing of eukaryotic nuclear pre-mRNA involves the recognition of specific splice sites at the $5^{\prime}$ and $3^{\prime}$ borders of the intron and at an internal branch point within the intron (Rogers and Wall, 1980; Lerner et al., 1980), by a group of small nuclear ribonucleoprotein particles (snRNPs). In general, the pre-mRNA and snRNPs form a complex, called a spliceosome, with these required components; ATP (Bindereif and Green, 1986), functional splice sites and branch point, snRNPs (Grabowski et al., 1985; Frendeway and Keller, 1985), heterogeneous nuclear ribonucleoproteins (Choi et al., 1986), and other protein factors. After transcription past the $3^{\prime}$ splice site, the spliceosome begins to assemble. The first step in splicing is 
the interaction of the U1 snRNP with the 5 ' splice site (Zhuang and Weiner, 1986) followed by cleavage at the site. The 5' phosphate of the cleaved intron becomes esterified with the 2 ' hydroxyl group of a conserved adenosine residue in the branch point sequence, which is associated the U2 snRNP, thus forming a lariat structure. The splice intermediates (exon 1 and lariat + exon 2) are held in close proximity by the spliceosome complex (Grabowski et al., 1985; Grabowski and Sharp, 1986; Frendeway and Keller, 1985). U4 and U6 snRNPs are also associated with the spliceosome but their exact function is not known (Chabot and Steitz, 1987). Next, the 3' splice site, in association with U5 snRNP (Chabot, 1985), is cleaved and concomitantly, the two exon fragments are ligated. This releases the intron in a lariat form (Padget et al., 1984; Ruskin et al., 1984), see Figure 1 and Appendix 1.

Splicing of pre-mRNA was described in 1977 by Chow et al., Berget et al. and Klessig in their work on adenovirus 2 (Ad 2). Since that time, much work with in vitro transcription systems has further elucidated Ad 2 processing (Manley et al., 1979; Manley et al., 1980; Padget et al., 1983). Viral splicing has also been identified in SV40 and polyoma viruses (Fromm and Berg, 1983b; Berk and Sharp, 1978,; Friedmann et al., 1979; Buchman et al., 1984; F. Chu, 1987).

Splicing of hnRNA has been described in all of the eukaryotic organisms studied to date. Some examples are yeast (Siliciano and Guthrie, 1988), Drosophila (Beyer and Osheim, 1988), chicken ovalbumin (Breathnach et al., 1978), mammals (Reed and Maniatis, 1988), murine hemoglobin (Tilghman et al., 1978) and immunoglobulin light chain switching (Hozumi and Tonegawa, 1976; Rabbitts et al., 1978; Tonegawa, 1983). Splicing is also observed in plant pre-mRNA.

Although much is known about pre-mRNAs in mammals and yeast (reviewed in Green, 1986 and Padget et al., 1986), relatively little is known about pre-mRNA processing in plants. It is known that the $5^{\prime}$ and $3^{\prime}$ splice sites of higher plants (Slighton et al., 1983 ; 


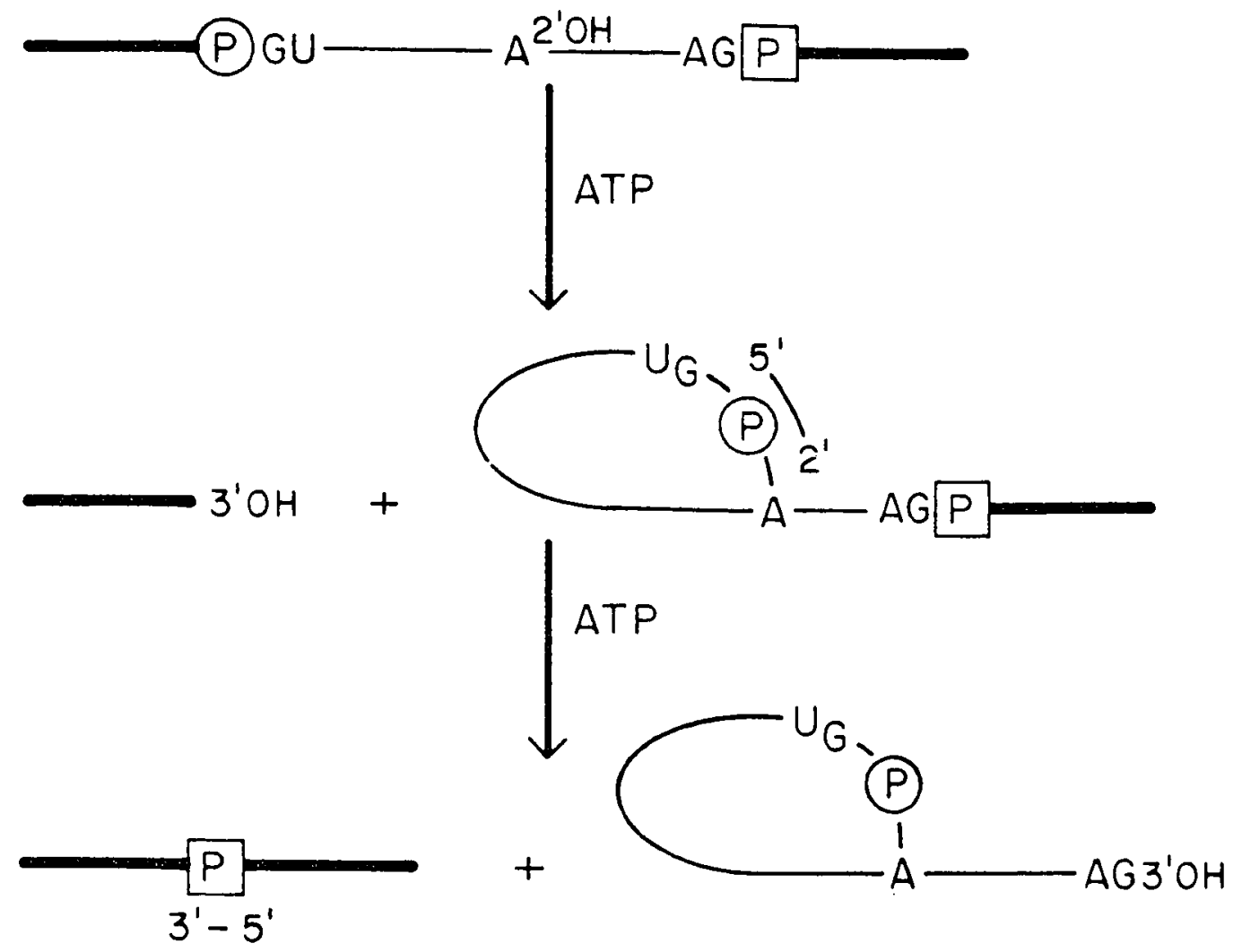

Figure 1. Mechanism of nuclear pre-mRNA splicing. This reaction requires multiple factors, including proteins and snRNPs. (figure from Transcription and Splicing. 1988. D.B. Hames and D.M. Glover, IRL Press, Oxford.) 
Rogers, 1985) do conform to the animal splice consensus sequences (Mount, 1982; Brown, 1986a). Plants do not possess the pronounced polypyrimidine tract, upstream of the $3^{\prime}$ splice site, as is observed in vertebrates. However, plants do contain snRNPs similar to vertebrate snRNPs (Krol and Ebel, 1983; Skuzeski and Jendrisak, 1985; Kiss et al., 1985). Brown (1986a) reported that the putative plant branch point sequences were very similar to vertebrate sequences.

This similarity between vertebrate and plant intron consensus sequences was not simply coincidence. In HeLa cells extracts, Brown et al. (1986b) found that introns from the wheat amylase gene were accurately processed while introns from the pea legumin gene were not. This was the first report which compared the processing of different monocot and dicot introns in an animal system. Barta et al. (1986) showed that human growth hormone pre-mRNA was not processed in transgenic tobacco or sunflower callus tissue. V. van Santen and Sprinzl (1987) showed the accurate splicing of two monocot transcripts, maize bronze and oat phytochrome type 3, in HeLa extracts. That same study also found a result similar to Brown's, namely, a dicot transcript (bean phaseolin gene) was not processed by HeLa extracts but was processed at low efficiency in intact monkey cells. Further, van Santen and Sprinzl (1987) showed that the intron 1 from human B-globin pre-mRNA was not spliced in tobacco cells. Again, this demonstated that there are striking similarities between vertebrate and plant splicing sequences, but these two systems are by no means interchangable. It also supported Brown's findings that monocot and dicot pre-mRNA's were processed with varying efficiencies in HeLa extracts.

Further studies (Wiebauer et al., 1988) suggested that plants and animals had different modes of $3^{\prime}$ splice site selection, probably related to the reduced polypyrimidine tract near plant $3^{\prime}$ splice sites. This study also noted that in dicots and monocots, the \% (Adenine + Thymidine) differs at the intron/exon border, from 74.3/55.0\% and $58.7 / 42.7 \%(\mathrm{~A}+\mathrm{T})$, respectively. This same $\%(\mathrm{~A}+\mathrm{T})$ at the intron/exon transition regions was not seen in the vertebrate genes 
inspected. The author suggested that this change in nucleotide composition may be important in plant pre-mRNA splicing.

As discussed above, there is no observable deviation from the consensus splice and branch sites between monocot and dicot premRNA's. However, there seems to be a difference in percent nucleotide composition. Keith and Chua (1986) reported that monocot and dicot pre-mRNA's were processed with different efficiencies in the one system tested, transgenic tobacco plants. In this case, the wheat $\mathrm{rbcS}$ gene and the maize Adh1 gene were not processed correctly in tobacco. However, a dicot pea rbcS transcript was processed efficiently in tobacco. These same constructs were not tested in a monocot system. It is important to note that the studies were done in different expression systems. Despite these system differences, the same conclusions were indicated in each case. The information from these studies demonstrated that monocot and dicot introns were processed with different efficiencies in both plant and HeLa extracts, dicot tissues did not process mammalian pre-mRNAs and, in these particular cases, monocot introns (genes) behaved more like mammalian transcripts than did dicot transcripts.

Gene Regulation at the Intron Level

Given that introns are present in the DNA of a great variety of eukaryotic organisms the question of intron function must be addressed. Are introns so ubiquitously present to simply act as substrates for vestigial splicing and ligation of adjacent exons, or can introns have a more important function? Can introns be involved in gene regulation and expression?

In the review, "On the Antiquity of Introns," Gilbert et al. (1986) concludes by saying, "Only the genes of the slowly replicating cells of complex organisms still retain the full stigmata of their birth". This reference to the possible vestigial nature of introns in modern genes may be correct in certain instances. In a study of Drosophila introns, Bingham et al. (1988), reported that introns ranging from 54 
to 75 bases in length appear to have no additional functions, other than to act as splicing substrates. However, this small sized class of introns was not representative of all introns or their possible functions. The inclusion of introns within a transcription unit may have been an evolutionary advantage. Thus, selective pressure for versatility and "resistance" to deleterious mutations may have preserved introns in modern eukaryotic genes. In general, the ability of an organism's splicing machinery to change efficiency of intron splicing, splice site selection or avoid splicing altogether, thereby changing the order of exons or by deleting large stretches of exon, can have a large effect on gene expression (Greer and Abelson, 1984). In this manner, entirely new proteins can be expressed under certain circumstances, or various changes in protein/gene expression can be achieved.

Expression of genes containing introns can be regulated in an "on/off" fashion. Bingham et al. (1988) demonstrated that "cell-type" specific expression of the Drosophila $P$ element was determined by allowing intron splicing to occur in germ line cells but not in somatic cells, leading to gene expression only in germ cells. Bingham also showed developmentally regulated intron excision and subsequent feedback regulation in the "suppressor of white apricot" locus $\left[\mathrm{su}\left(\mathrm{w}^{\mathrm{a}}\right)\right]$ of Drosophila. In this instance, the su(wa) protein negatively autoregulates its production during postembryonic development by repressing the removal of the first intron in the gene, thereby creating "blocked", inactive transcripts. Another example of gene regulation at the intron level is the transformed (tra) locus of Drosophila. In this case, by selecting a different 3 ' splice site for the tra intron 1, (a proximal site 76 bases from the $5^{\prime}$ site or a more distal site 247 bases from the 5 ' splice site), the sex of the embryo is determined. In two of the examples above, su(wa) and tra, the proteins produced by these transcripts have arginine and serine rich carboxy-terminal domains (Chou et al., 1987; Boggs et al., 1987). These regions are similar to proteins which tightly bind to nucleotides, called protamines (Warrant and Kim, 1978), thus 
providing a possible mechanism for gene regulation. Interestingly, this same type of domain is present in the protein of the U1 snRNP.

In addition to gene regulation by certain intron splicing events, regulation may be due to the sequences within the intron itself. Some introns contain enhancer elements. True enhancers may be tissue or cell type restricted, and are independent of position, orientation and proximity with respect to the gene and its promoter. Enhancer sequences were first noted in the early cap site of Simian Virus 40 (SV40) (Moreau et al., 1981; Banerji et al., 1981; Fromm and Berg, 1983a) and the histone H2A gene (Grosschedl and Birnstiel, 1980). Enhancers affect gene expression by increasing the transcriptional activation of a gene, not co- or post-transcriptional processing of the transcript. Examples of enhancers within introns are found in the murine immunoglobulin heavy (Gillies et al., 1983; Mercola et al., 1983) and light chains (Spandidos and Anderson, 1984; Picard and Schaffer, 1984), between the variable and constant regions of the corresponding genes. Due to recombination events during B-cell differentiation, certain promoters and genes are brought into close proximity with an enhancer and are thereby activated to give functional transcripts.

Intron Dependent and Intron Independent Gene Expression

Genes containing introns may be regulated in an intron dependent or independent manner. In some cases, the introns may be required for pre-mRNA stability. Buchman and Berg (1988) demonstrated the intron dependent nature of the rabbit B-globin gene in CVIP cells infected with recombinant SV40. The cDNA derived B-globin clone was expressed at very low levels in infected cells. When the B-globin intron 1 or 2 was "reintroduced" into the clones, they observed a 400 fold increase in gene expression. Through deletion analysis of the intron, it was deduced that the actual sequences required for mRNA stabilization and subsequent increase in gene expression, were located at the splice junctions. Even 
when the intron was reduced from 573 bases to 66 bases, splicing and increased gene expression were observed. Only when the $5^{\prime}$ and 3' splice junctions were changed did the activity drop to "no intron" levels. Introns derived from SV40 would also increase B-globin levels. However, intron additions failed to restore gene activity if placed outside of the transcription unit, evidence that the introns did not contain "enhancer" elements.

This work agrees with the findings reported by Hamer et al. (1979a), in studies of other recombinant SV40 viruses. Brinster et al. (1988) recently reported that introns increase the transcription rate of genes that were introduced in transgenic mice. However, no increase in gene expression was observed in cultures of mammalian cells transformed with the same viruses. Buchman and Berg (1988) also described the intron independent nature of the herpes simplex virus thymidine kinase $(t k)$ gene, a gene which lacks introns. The addition of the rabbit $B$-globin second intron to constructs, containing the $B$-globin gene and the $t k$ promoter and polyadenylation sequence, led to a 20 fold increase in B-globin expression. When the intron was added to a construct containing both the $B$-globin and the $t k$ transcribed region, only a two fold increase in B-globin activity was noted. This demonstrated that the sequence responsible for the intron independent transcription was present in the $t k$ gene coding region.

Therefore, it appears that introns can play a major role in the regulation of genes they are within and genes from proximal regions of the genome. Introns inserted into foreign gene systems may also have a regulatory influence under certain circumstances. However, as indicated by these studies, a particular intron may not be equally effective in all cell types. Factors influencing intron related expression of a gene may include inefficient processing, incorrect processing or failure to recognize splice sites in a particular cell system. 
Gene Transfer Systems

Any reproducible gene transfer system can be very important in the study of transient or stable gene expression in animal and plant systems. Gene transfer systems can be grouped into 3 main categories; biological, chemical and physical. Biological gene transfer methods include Agrobacterium mediated $\mathrm{Ti}$ recombination (limited to dicot species) (Bevan et al., 1983; Herrera-Estrella et al., 1983; Fraley et al., 1984; Chee et al., 1986) and retroviral integration (Hamer et al., 1979a; Mulligan et al., 1979). Chemical transfer methods include the use of $\mathrm{CaPO}_{4}$ (Graham and van der $\mathrm{Ed}, 1973$ ), DEAE-Dextran (McCutchan and Pagano, 1968), polyethylene glycol (Jonak et al., 1984) and liposome fusion (Fraley et al., 1980; Wong et al., 1980; Machy et al., 1988). Physical gene transfer can be achieved using laser micropuncture (Tsukakoshi et al., 1984; Tao et al., 1987), microinjection (Graessmann and Graessmann, 1976), projectile transformation (particle gun) (Klein et al., 1987), and electroporation. All of these gene transfer methods can produce DNA damage or mutations, low transformation efficiency or cell death. In plant protoplast expression systems, electroporation achieves the highest transformation efficiency and cell viability.

Many studies have used electroporation to transfer genes into plants and animal cells. Zimmerman and Scheurich(1981) achieved plant cell fusions by "manual" discharge electroporation. Neumann et al. (1982) worked with fibroblast (mouse L cell) transformation and Potter et al. (1984) utilized electroporation mouse pre-B lymphocytes. Using such a capacitor system to ensure an even discharge of electricity, investigators achieved transient expression of genes in carrot and maize protoplasts. This same type of system was also successful in mesophyll protoplasts of Avena, Zea, Vigna. petunia, and amaranthis (Bates et al., 1983) and mammalian cells (Howard, 1983; Gorman, 1982; G. Chu, 1987).

The quick, reproducible results achieved through electroporation make it an ideal system for studying the effects of 
intron processing in native and chimeric genes. In plant cells, the first electroporation experiments with chimeric gene constructs utilized genes which lacked introns (Bevan et al., 1983; HerreraEstrella et al., 1983). In one study which did examine the effect of introns, they found that the phaseolin gene (which contains introns) was expressed in an intron independent manner (Chee et al., 1986). Consequently, it was assumed that introns were not important for plant gene expression.

However, recent studies have proven the importance of introns in plant gene expression. Callis et al. (1987) showed normal expression of the maize alcohol dehydrogenase (Adh1) gene in stable maize transformants, but very low expression of a cDNA derived Adh1 clone in maize protoplasts. By placing the Adh1 intron 1 (one of nine in the native gene) in the region between the promoter and the coding region of the gene, gene activity was restored to levels seen with the intact gene. In a chimeric gene, composed of the Adh1 $5^{\prime}$ promoter, the chloramphenicol acetyltransferase gene (CAT) and the Adh1 3' polyadenylation region, gene activity was increased 100 fold upon addition of the Adh1 intron 1. The same effect was seen in intron-CAT chimeras containing the CaMV $35 \mathrm{~S}$ promoter. Similar results were seen with the intron from the maize Bronze 1 locus.

The discovery of introns has opened a whole new field of investigation, the study of RNA processing. Introns are present in almost all eukaryotic organisms and are important in gene regulation. While some introns can increase gene expression due to enhancers within their sequences, other interesting introns can enhance gene expression merely by being correctly spliced. In plants, certain studied introns can increase gene expression of foreign, non-intron containing genes. Therefore, we may be able to use introns to help selectively overexpress desired agronomic genes and traits in important crop plants. A much more detailed study of intron splicing is necessary. 
This investigation will attempt to further illustrate the effects of a dicot derived intron (soybean rbcS intron 1) on chimeric gene expression in both a monocot (maize) and dicot (carrot) transient expression system. 
Materials and Methods

Enzymes and Reagents. Restriction enzymes were obtained from New England Biolabs (Beverly, MA.) or Bethesda Research Laboratories (Gaithersburg, MD.) and used under conditions described by the manufacturer. Enzymes used for creating protoplasts were from Calbiochem (San Diego, CA.). Ligase buffer containing ATP was obtained from International Biotechnologies, Inc. (New Haven, CT.). Low melting Seaplaque agarose was obtained from FMC Bioproducts (Rockland, ME.). Other agarose was obtained from Biorad (Richmond, CA.), ultrapure reagents. Other chemicals were from Sigma (St. Louis, MA.) and Difco Laboratories (Detroit, MI.). Lab supplies, glassware and Type 57 Polaroid film were obtained from VWR Scientific (San Francisco, CA.)

Starting Plasmids. The plasmids containing the desired sequences were pSRS2.1 (rbcS construct; Berry-Lowe et al., 1982), pZO19 (CaMV 35S promoter; Dietrich et al., 1987), pHS 3 (Brassica heat shock promoter; Cannon et al., 1987) and pZO30 (no promotermulticloning site-CAT-Nos; Alfinito et al., 1987). Elements from all of these were used to construct plasmids with either the CaMV $35 \mathrm{~S}$ or the Brassica heat shock promoter, a multicloning site, the chloramphenicol acetyltransferase gene and the nopaline synthase termination sequence. All of these plasmids were originally derived from the ampicillin resistant plasmid, pUC19 (Yanish-Perren et al., 1985); therefore all subsequent constructs are ampicillin resistant. Accordingly, isolation and growth of recombinant bacterial colonies were done in media supplemented with $50 \mu \mathrm{g} / \mathrm{ml}$ ampicillin (Amp50).

Preparation of Competent E.coli JM83. The protocol used for JM83 was an adaptation of the one described by Kushner (1978), see Appendix 2 for protocol. Transformation of JM83 with recombinant plasmids was also done as described by Kushner. Variations of this protocol are also in Appendix 3. 
Small Scale Isolation of Plasmid DNA. Small amounts of plasmid DNA (5 to $20 \mu \mathrm{g}$ ) were obtained using the alkaline lysis method of Birnboim and Doly (1979). Ampicillin resistant colonies were inoculated into $2 \mathrm{mls}$ of liquid LB (Bertani, 1951) media, supplemented with ampicillin $(50 \mu \mathrm{g} / \mathrm{ml})$, and incubated overnight at $37^{\circ} \mathrm{C}$ with vigorous shaking. Changes from the above procedure include a $15 \mathrm{~min}$ protein/chromosomal DNA precipitation instead of 60 minutes, followed by ethanol precipitation of nucleic acid from all of the cleared supernatant. The plasmid pellet was resuspended in $50 \mu \mathrm{l}$ TE (10 mM Tris- $\mathrm{HCl}, 1 \mathrm{mM}$ EDTA), plus $0.5 \mu \mathrm{g} / \mathrm{ul}$ DNase-free RNase A. The resulting plasmid DNA is suitable for restriction enzyme digestion, electrophoretic analysis and further cloning procedures.

Large Scale Isolation and Purification of Plasmid DNA. If large amounts of a particular plasmid construct were needed, the colony corresponding to the DNA (prepared as above) which showed the correct restriction digest pattern was inoculated into $500 \mathrm{ml}$ of "Terrific Broth" (Tartoff and Hobbs, 1987) supplemented with 50 $\mu \mathrm{g} / \mathrm{ml}$ ampicillin in a $2 \mathrm{~L}$ flask and incubated overnight at $37^{\circ} \mathrm{C}$, with vigorous shaking. Plasmid DNA was extracted by the alkaline lysis method, scaled up from method of Birnboim and Doly (1979), except solution 1 contains $20 \mathrm{mg} / \mathrm{ml}$ lysozyme instead of $2 \mathrm{mg} / \mathrm{ml}$. The plasmid pellet was resuspended in $3 \mathrm{ml}$ of TE then purified in a cesium chloride/ethidium bromide density gradient, underlayering method, as described by Garger et al. (1983). A Beckman L8-80M ultracentrifuge and Ti80 rotor were used (Beckman Instruments, Palo Alto, CA.). The resulting band of plasmid DNA was pulled from the quick-seal ultracentifuge tube by side puncture with an 18 gauge needle and syringe. Three volumes of TE were added, the mixture was quickly extracted to clarity with TE saturated isoamyl alcohol and precipitated with 2 volumes of $100 \%$ ethanol at $-20^{\circ} \mathrm{C}$. No extra salts were added. The purified plasmid was resuspended in $1 \mathrm{ml}$ of 
TE. This method can produce up to $12 \mathrm{mg}$ of pure DNA measured by absorbance at $260 \mathrm{~nm}$, on a Beckman DU Spectrophotometer.

Agarose Gel Electrophoresis. To resolve DNA fragments larger than 500 basepairs in length, samples were electrophoresed in $0.8 \%$ agarose gels in 1xTAE buffer (0.04 M Tris-acetate, $0.001 \mathrm{M}$ EDTA) at $5 \mathrm{~V} / \mathrm{cm}$. The EPS-250 mini power supply (American Bionuclear, Emeryville, CA.) was used under constant voltage. Fragments smaller than this were electrophoresed in $2 \%$ agarose, $1 \times$ TBE buffer $(0.1 \mathrm{M}$ Tris base, $0.001 \mathrm{M}$ EDTA, $0.08 \mathrm{M}$ boric acid), at $8 \mathrm{~V} / \mathrm{cm}$. The corresponding percent low melting Seaplaque agarose was used for isolation of these fragment sizes for cloning purposes. DNA samples were loaded into wells in 10-15 $\mu 1 \mathrm{TE}$ and type 2 loading buffer, as described by Maniatis et al. (1982, pg.160). Samples prepared for restriction analysis were electrophoresed with $1 \mu \mathrm{g} / \mathrm{ml}$ of ethidium bromide (Sharp, 1973) in the running buffer and photographed under ultraviolet (UV) light. Samples to be isolated for cloning were briefly stained in running buffer and $1 \mu \mathrm{g} / \mathrm{ml}$ ethidium bromide after electrophoresis, photographed in UV light (using a short wave UV protective screen under the gel) and appropriate bands were cut out of the gel with a scalpel.

Ligation and Transformation. Cloning techniques were as described by Maniatis et al. (1982) and the International Biotechnologies, Inc. catalog (1986-87). All ligations containing the desired fragments, isolated in low melting Seaplaque, melted at $55^{\circ} \mathrm{C}$, were brought to a final volume of $50 \mu \mathrm{l}$ and incubated overnight at $25^{\circ} \mathrm{C}$. The ligation reaction was transformed into competent E. coli JM83 the following day.

Construction of Promoter Constructs. See Figure 2 for outline of cloning scheme. All of the promoter plasmids were based on pZO30. pZO30 was cut with Sst I (an isoschizomer of Sac I) and treated with bacterial alkaline phosphatase (BAP) to prevent ligation of the $5^{\prime}$ 


\section{Promoter Cloning Strategy}

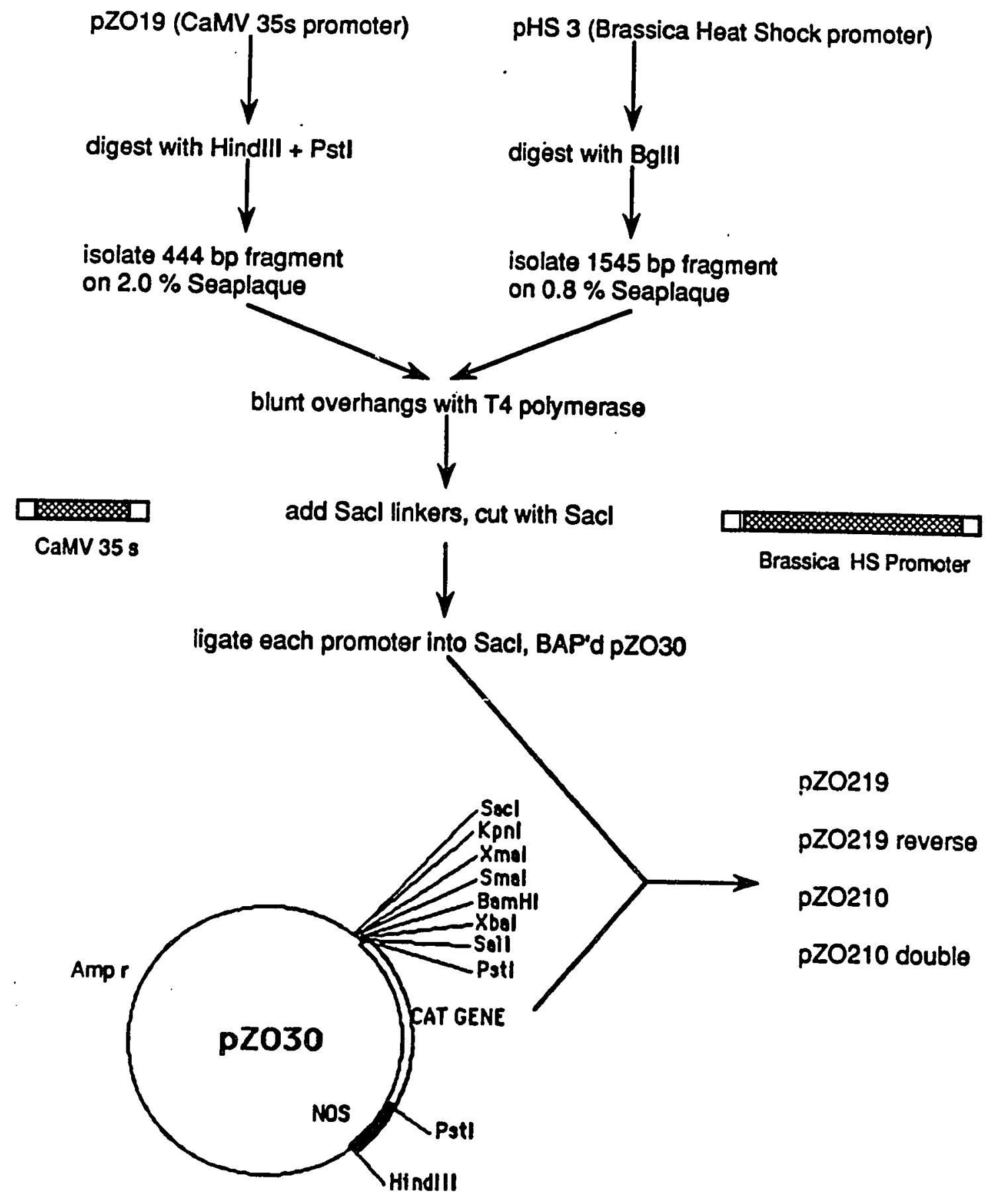

Figure 2. The promoter cassettes were constructed following this strategy. 
overhangs left by the Sst I cut. The CaMV $35 S$ promoter was isolated by gel electrophoresis from $\mathrm{pZO19}$ on a Hind III/Pst I restriction fragment (444 base pairs). The Brassica heat shock promoter was isolated from pHS 3 on a $B g l$ II restriction fragment (1545 bp). The two promoter fragments were then polished with T4 DNA polymerase as described by Maniatis (1982, page 394). 5xTA buffer (O'Farrell and Weissman, 1981) was used in blunting reactions. Phosphorylated Sac I linkers were then ligated to the blunt ended promoters (1:50 linker to fragment picomole end ratio) with T4 DNA ligase. Although Maniatis recommends allowing blunt end ligations to react for 2 hours, the method used required only 30 minutes at $37^{\circ} \mathrm{C}$ with the ligase buffer from International Biotechnologies Inc. The above fragments were cut with $S a c 1$ and ligated into the pZO30 cut with Sst 1. Large amounts (1-12 mg) of these promoter constructs were purified.

Construction of Intron Inserts in Promoter Constructs. Desired intron fragments were cut from pSRS2.1 and isolated in $2.0 \%$ Seaplaque. Bam HI linkers were added to the ends of the intron fragments, which were then subcloned into the Bluescript $\mathrm{KS}+$ vector (Stratagene, San Diego, CA.). Transformed colonies were digested with appropriate restriction enzymes and analyzed by gel electrophoresis to determine if the correctly sized intron fragment had been inserted. The desired fragments were then ligated into each of the promoter plasmids (digested with Bam $\mathrm{HI}$ and treated with bacterial alkaline phosphatase). JM83 cells were transformed with the resulting intron constructs. Transformed colonies containing plasmids with the correctly sized Bam HI intron fragments were grown in TB Amp 50 and plasmid DNA was isolated, see Figure 3.

Bacterial Freezer Stocks. Small portions of each $500 \mathrm{ml}$ bacterial culture, from which the cloned plasmids were isolated, were diluted in an equal volume of sterile freezing media (Schleif and Wensink, 1981) and transfered to freezing vials. The samples were 


\section{Intron Cloning Strategy}

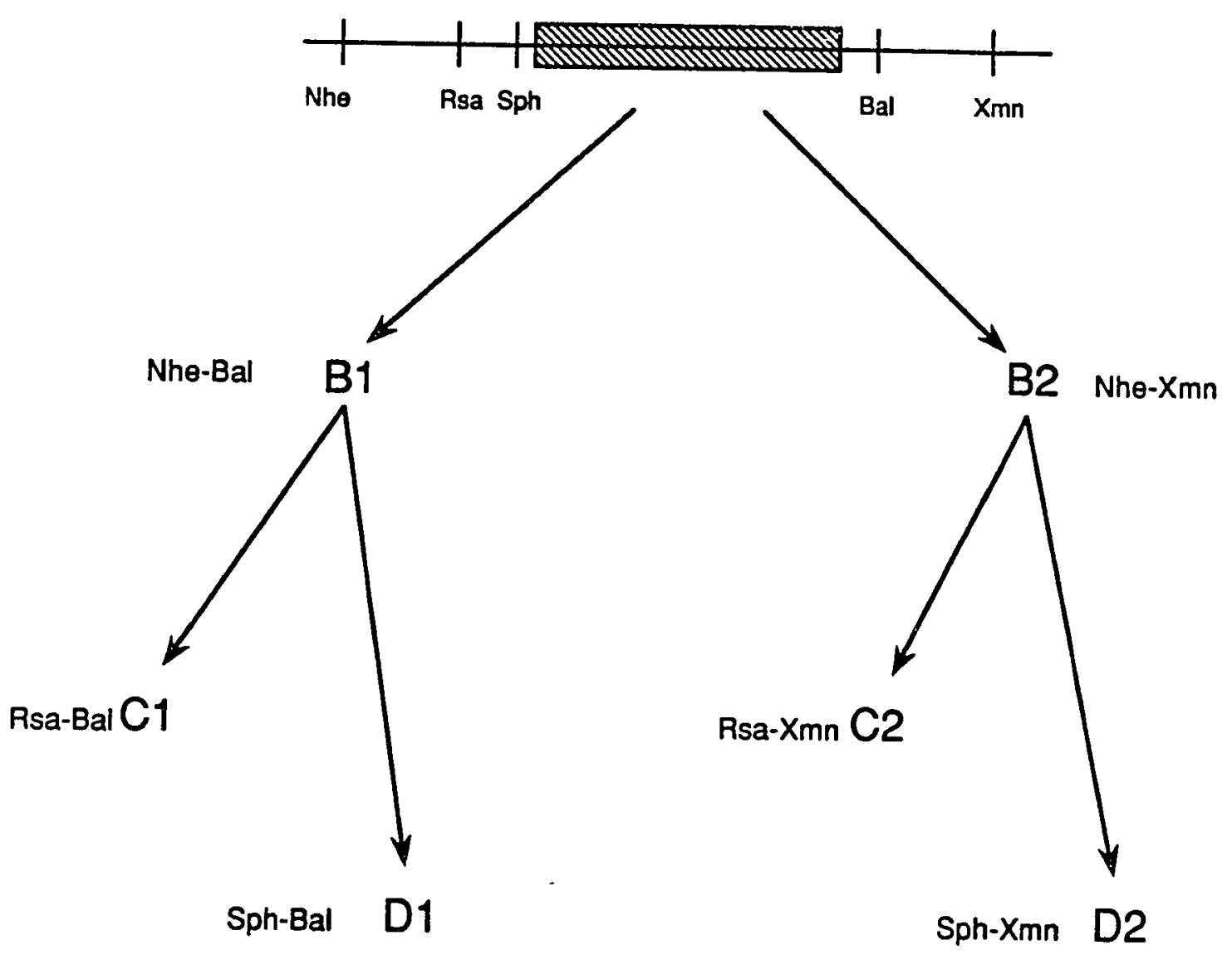

Figure 3. The above fragments were subcloned into the Bluescript $\mathrm{KS}+$ vector with the addition of BamHI linkers. Fragments were then cloned into pZO210, pZO210double, pZO219 and pZO219reverse in the BamHI site of the 5' untranslated leader of the CAT gene. 
rapidly frozen in liquid nitrogen and stored at $-80^{\circ} \mathrm{C}$.

Carrot and Maize Cell Line Maintenance. The carrot cell line, Redwood City wild carrot (RCWC) was supplied by Joe Ecker, Stanford University and was passaged by diluting 1:10 into sterile carrot suspension media $(500 \mathrm{mls} ; 1 \mathrm{x}$ MS salts (Murashige and Skoog, 1962 ), $0.5 \mathrm{mg}$ nicotinic acid, $0.5 \mathrm{mg}$ pyridoxine $\mathrm{HCl}, 0.5 \mathrm{mg}$ thiamine,

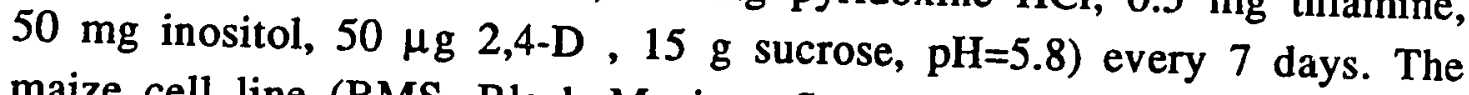
maize cell line (BMS, Black Mexican Sweet), was diluted 1:1 in sterile suspension media $(500 \mathrm{mls}$; $1 \mathrm{x}$ MS salts, $10 \mathrm{~g}$ sucrose, $65 \mathrm{mg}$ asparagine, vitamins as above, $100 \mathrm{mg}$ inositol, $1 \mathrm{mg} \mathrm{2,4-D,pH=5.8)}$ twice a week. Carrot cultures were grown at room temperature on a shaker table. Maize cultures were maintained at $28^{\circ} \mathrm{C}$, shaking.

Protoplast Production. Protoplasts were produced from carrot cultures four days after transfer to fresh media. Corn cells were used three days after transfer. Desired volumes of carrot or corn suspension cultures were gently centrifuged $(1000 \mathrm{rpm}, 162 \mathrm{~g}$ for 3 minutes). Supernatant was aspirated and appropriate enzyme solutions were added. Carrot enzyme solution ( $1 \%$ cellulysin, $0.5 \%$ hemicellulase, $0.4 \mathrm{M}$ mannitol, $50 \mathrm{mM} \mathrm{CaCl}, 10 \mathrm{mM} \mathrm{NaAc}, \mathrm{pH}=5.8$, filter sterilized, $2 \mu \mathrm{m}$ ) was added to equal the initial volume of suspension culture. Corn enzyme solution (1\% cellulysin, $0.5 \%$ hemicellulase, $0.02 \%$ pectinase, $0.5 \%$ BSA w:v, $0.5 \%$ beta mercaptoethanol v:v) was used at $5 \mathrm{ml} / \mathrm{g}$ corn tissue. The enzyme/cell combination was gently rotated at room temperature for 2 hours. The cells were then gently centrifuged and washed 3 times with carrot cuilture media ( $500 \mathrm{mls}$; same as carrot suspension media supplemented with $36.44 \mathrm{~g}$ mannitol) or maize protoplast buffer

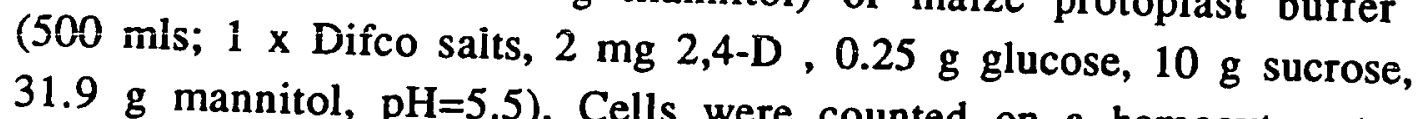
$31.9 \mathrm{~g}$ mannitol, $\mathrm{pH}=5.5$ ). Cells were counted on a hemocytometer at a 1:10 dilution ( $3 \mu 1$ in $27 \mu 1$ culture media). One $50 \mathrm{ml}$ carrot suspension yields up to $1.7 \times 10^{8}$ protoplasts. Corn cultures produce from $1-1.5 \times 10^{7}$ protoplasts from one $50 \mathrm{ml}$ culture. 
Electroporation. Electroporation was done in sterile 24 well microtiter plates. The PG 200 Progenitor II (Hoeffer, San Francisco, CA.) was used in conjunction with a $0.5 \mathrm{~cm}$ circular electrode. Carrot protoplasts were electroporated at a concentration of $1-2 \times 10^{6}$ cells per reaction. Corn cells were used at $0.5-1.0 \times 10^{6}$ cells/reaction. Protoplasts were resuspended in culture media to give the above desired cell concentration in $1 \mathrm{ml}$. Cells were split into $1 \mathrm{ml}$ portions, spun gently and supernatants were aspirated. The plasmid constructs to be tested were prepared as follows. In a $1.5 \mathrm{ml}$ microfuge tube, 30 $\mu \mathrm{g}$ of plasmid was added to $75 \mu \mathrm{l} 2 \mathrm{M} \mathrm{KCl}$. Approximately $860 \mu 1$ sterile culture media $(\mathrm{pH}=8.0$ ) was vigorously added to $\mathrm{DNA} / \mathrm{KCl}$. The resulting solution was gently mixed with the protoplasts, by pipetting down the side of reaction tube. The entire mixture (should be $1 \mathrm{ml}, 30 \mu \mathrm{g} / \mathrm{ml} \mathrm{DNA}$, adjust with volume of culture media used) was gently drawn into the pipette tip and transfered into a 24 well microtiter plate. The electrode was dipped in ethanol, flamed and then placed in the well containing the protoplasts and DNA, and the electric charge was delivered, see Figure 4. Carrot cells were treated with $250 \mathrm{~V}(500 \mathrm{~V} / \mathrm{cm})$ at $1200 \mu \mathrm{f}$ for $100 \mathrm{msec}$ for optimum cell survival and activity. Corn cells were treated with $200 \mathrm{~V}(400$ $\mathrm{V} / \mathrm{cm}), 1200 \mu \mathrm{f}$ for $100 \mathrm{msec}$. Duplicates of each sample were treated as well as a "no DNA" control. After electroporation, the cells were gently transfered to $100 \mathrm{~mm} \times 15 \mathrm{~mm}$ sterile petri plates and $5 \mathrm{ml}$ culture media $(\mathrm{pH}=5.8)$ was added. The confluent cells were stored at room temperature overnight.

Transient Chloramphenicol Acetyltransferase Assays. Assays were done on cells one day after electroporation. The cells were gently collected from the petri plate and pelleted in a $15 \mathrm{ml}$ conical bottom tube. The supernatant was carefully aspirated and replaced by $250 \mu \mathrm{l}$ of sterile $250 \mathrm{mM}$ Tris- $\mathrm{HCl}, 10 \mathrm{mM}$ EDTA. The mixture was then sonicated and heated at $65^{\circ} \mathrm{C}$ to disrupt the cell membranes, releasing the transiently expressed chloramphenicol acetyltransferase enzyme into the supernatant. Tubes were spun at 


\section{Electroporation}

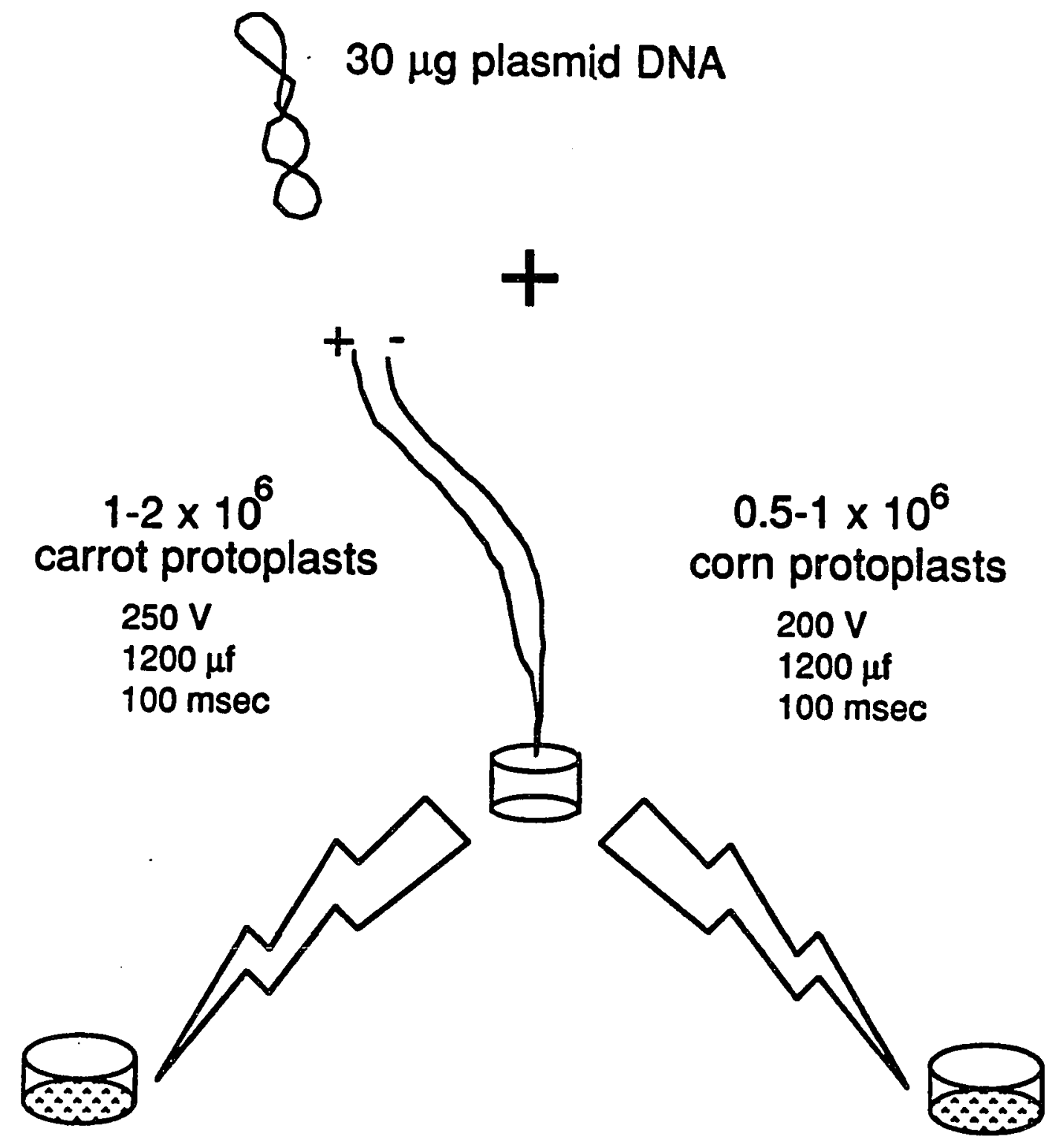

Figure 4. Schematic representation of the electroporation process. Electroporation is done in a 24 well microtiter dish under sterile conditions. 
high speed ( $2800 \mathrm{rpm}, 1272 \mathrm{~g}$ ) for $5 \mathrm{~min}$ to pellet the disrupted cells. The clear supernatants were removed and used for the assay. Similar to the methods of Young et al. (i985), to $200 \mu$ l supernatant the following solution was added: $0.075 \mathrm{mg}$ acetyl coenzyme $\mathrm{A}, 5 \mu \mathrm{g}$ purified chloramphenicol in $10 \mu \mathrm{lTE}$. This mixture was incubated at $37^{\circ} \mathrm{C}$ for 2 hours, then extracted with $400 \mu \mathrm{l}$ ethyl acetate. The ethyl acetate fraction was completely dried in a Savant Speed-Vac (20-30 $\mathrm{min})$ and resuspended thoroughly in $50 \mu 125 \%$ acetonitrile in water. The entire volume was loaded into a sample vial and analysed on the HPLC.

HPLC Analysis of Transient CAT Activity. The instrument used was a Hewlett-Packard 1090 liquid chromatograph. It was used in tandem with the HP Thinkjet and HP 3396 integrator. The HPLC was prepared as in Appendix 4. Run time was 9 minutes per sample and could be left to run overnight. Sample of data print out is shown in Figure 5. Peaks are identified and quantified by the integrator. Total percent acetylation was determined for each sample by adding the percent acetylation in the 1 -acetylated peak to the 3-acetylated peak. This value was normalized to the control plasmid activity (no intron, just the promoter cassette) by dividing the percent acetylation by the control percent acetylation. This value denotes the enzyme's relative activity in the intron constructs compared to the control constructs. An acetonitrile solvent system was used to resolve the peaks representing the various forms of acetylated chloramphenicol. A reverse phase, C18, $3 \mathrm{~cm}$ column from PerkinElmer was used (Pecosphere $3 \times 3 \mathrm{CR}$ ). 


\section{Sample HPLC Data}

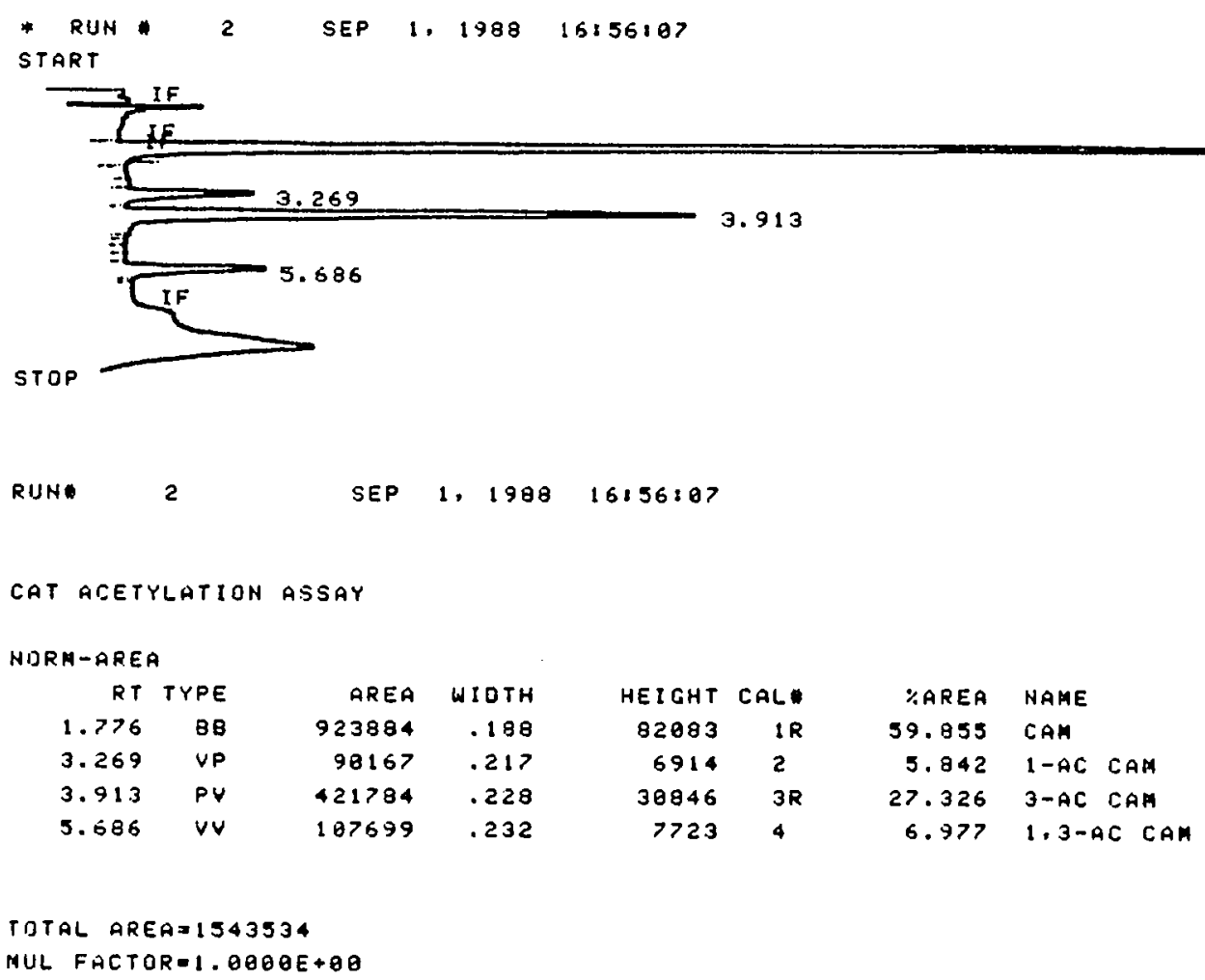

Figure 5. Sample HPLC printout of an acetylated chloramphenicol standard. The area and identity of each peak are given. In a test situation, the percent of 1-Acetylated (Ac), 3-Ac and 1,3-Ac chloramphenicol are added together then compared to the proper control value to determine the relative CAT activity for that test plasmid. 
Results

Plasmid Constructions

A series of plasmids were constructed to ascertain what effect a
dicot's intron would have on transient gene expression when inserted
into the $5^{\prime}$ untranslated leader region of into the $5^{\prime}$ untranslated leader region of a reporter gene. In those plasmids, the introns were placed in the $5^{\prime}$ untranslated region so that they would not change gene expression by interfering with the coding sequence, but rather by putative stabilization and splicing events in the pre-mRNA. For expression of a gene, plasmids must contain at least a promoter, a gene and a polyadenylation signal. Therefore, plasmids were constructed which contained the desired promoters and intron fragments, the chloramphenicol acetyltransferase (CAT) reporter gene and the nopaline synthase (Nos) polyadenylation region. The Nos region has been used in other studies (Dietrich et al., 1987) and was shown to act as an efficient termination signal. The CAT gene has also been used in similar studies (Fromm et al., 1985; Ecker and Davis, 1986; Hauptmann et al., 1987). The CAT enzyme is stable enough to remain active even with fairly vigorous isolation techniques and shows little loss of activity after one week of storage at $-20^{\circ} \mathrm{C}$ (extensive review by Shaw, 1983). Yet, the enzyme is sensitive enough such that small changes in activity can be easily detected.

Promoters chosen for this study were the Cauliflower mosaic virus 35S (CaMV 35S) promoter and a Brassica heat shock 80 promoter. Variations of the CaMV $35 \mathrm{~S}$ promoter has been used in numerous studies to express plant genes at detectable levels (Odell et al., 1985; Odell et al., 1987; Pierce et al., 1987; Dietrich and Walbot, 1988; Silva et al., 1988; Fang et al., 1989). This promoter gives high activity in carrot and maize. The Brassica heat shock promoter was used in this study to compare its activity to the CaMV $35 \mathrm{~S}$ promoter and as an example of a plant promoter used to express genes in a plant system. As a control point, both promoters were positioned the 
same distance from the CAT gene, see Figure 6. Constructs with the CaMV $35 S$ promoter were designated "pZO219" (promoter positioned in the expressed orientation with respect to the CAT gene) and

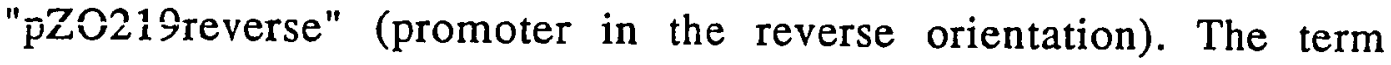
"expressed" indicates that the TATA box within the promoter is positioned 25 to 30 nucleotides from the reporter gene. "Reverse" indicates that the promoter is flipped, so the TATA box is at the distal side of the promoter, at some rather large distance from the reporter gene and on the opposite strand of DNA. If the promoter is in the reverse orientation, transcription will not occur and no gene expression can be detected. The plasmid, pZO219reverse and its intron containing derivatives gave no gene activity as expected and therefore, act as background controls for transient CAT expression assays. The plasmids containing the heat shock promoter were designated "pZO210" (promoter in expressed orientation) and "pZO210double" (two promoters, both in the expressed orientation). No clone was isolated which contained the Brassica promoter in the reverse orientation. The double Brassica promoter behaves the same as the single pZO210.

Once the promoter cassettes were constructed, various fragments of the soybean rbcS intron 1 and the surrounding exon sequences were inserted in the same site in each of the respective promoter cassetttes, as previously described in Figure 3. The desired intron fragments were isolated from pSRS2.1 (Berry-Lowe et al., 1982), BamHI linkers were added and the resulting intron pieces were cloned into the promoter cassette $B a m H I$ site. Figure 7 illustrates the varying $5^{\prime}$ and $3^{\prime}$ exon lengths which were left on the intron fragments. These exon sequences were included to assure that the natural splice site remained and to observe any differences in transient gene expression due to the more distal exon regions. The introns were designated B1 (32 bp 5' exon, 7 bp 3'exon), B2 (32 bp 


\section{Promoter Cassettes}
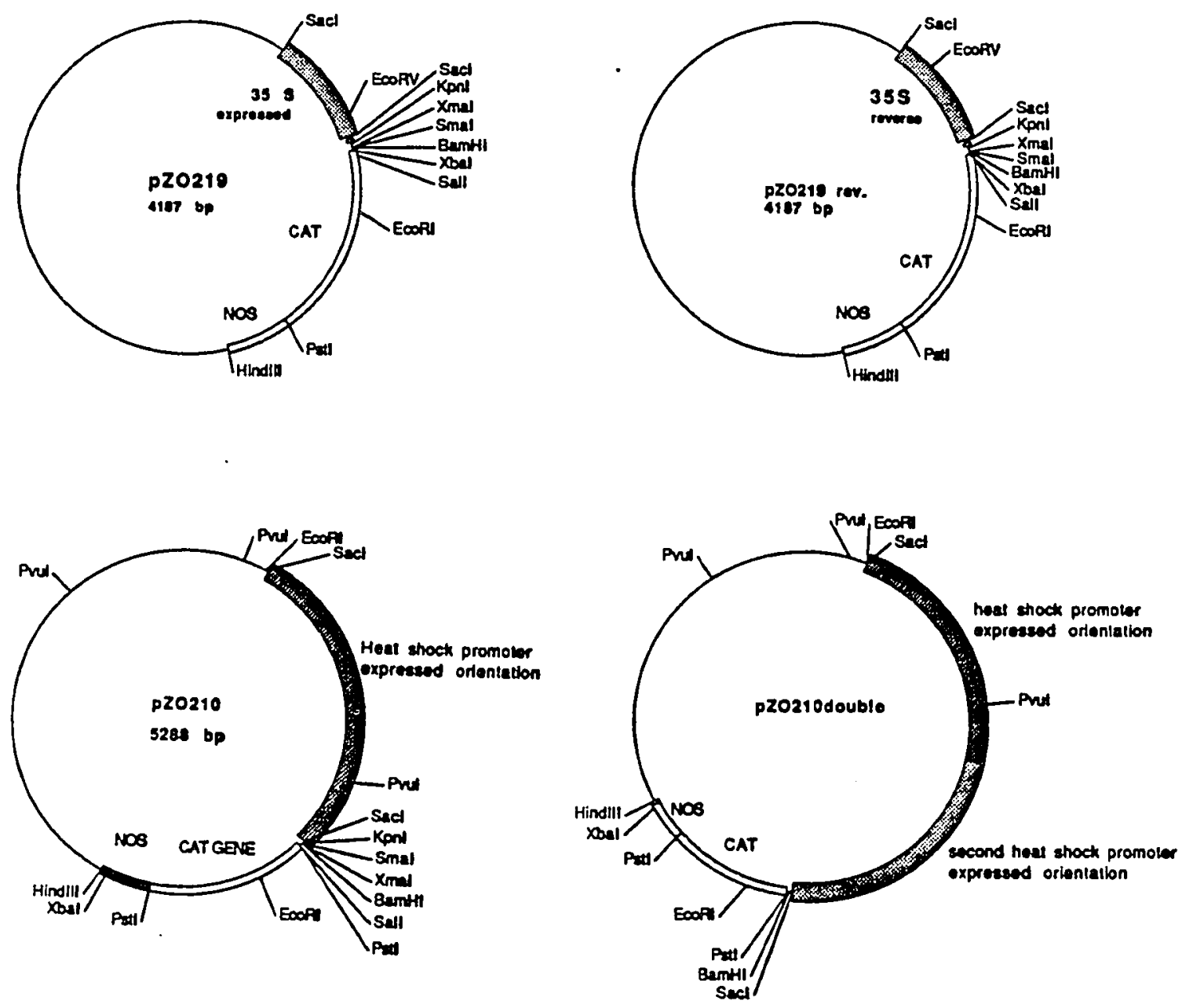

Figure 6. Promoter cassettes were constructed which contained the CaMV $35 S$ promoter or a Brassica heat shock promoter, the CAT gene and the Nos termination region. Note, all promoters were inserted into the $S a c$ I site. 


\section{Intron Fragments}

\section{soybean rbc $S$ INTRON 1 pSRS2.1}

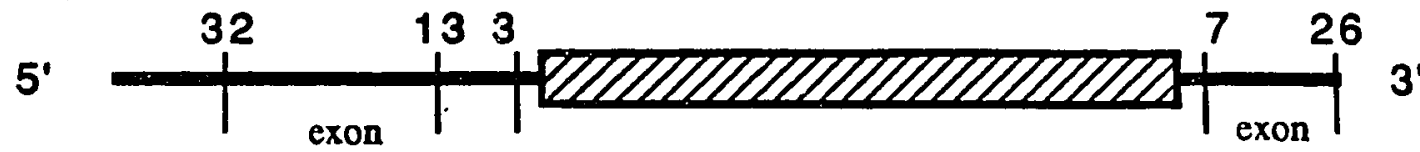

Nhe | Rsa ! Sph I 192 BP $\quad$ Bal I Xmn I

fragment langth Including linkere

B1 243

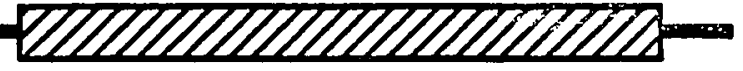

B 2262

C 1224

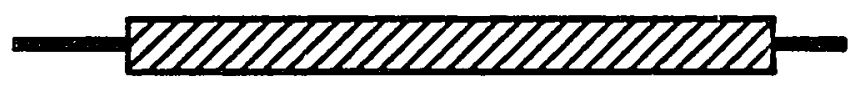

C $2 \quad 243$

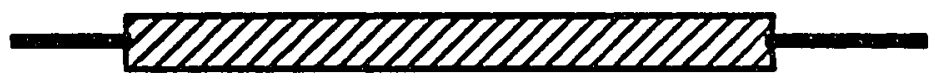

$\begin{array}{ll}\text { D1 } & 214 \\ \text { D2 } & 233\end{array}$
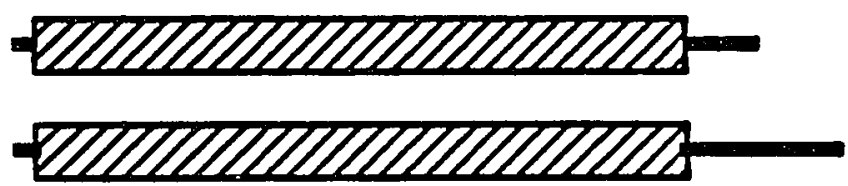

Figure 7. Intron fragments for cloning into promoter cassettes.

Note the changes in the $5^{\prime}$ and $3^{\prime}$ flanking exon sequences. 
5', 26 bp 3'), C1 (13 bp 5', 7 bp 3'), C2 (13 bp 5', 26 bp 3'), D1 (3 bp 5', 7 bp 3') and D2 (3 bp 5', 26 bp 3'). The addition of BamHI linkers to both ends of the fragment made it possible to isolate intron inserts in both orientations. All of the intron containing plasmids which were isolated, purified and tested for transient activity are shown in

Figure 8. Plasmids containing introns in the reverse orientation act as negative controls with the assumption that splicing does not occur. The reverse order splice junctions are not recognized by snRNPs and are therefore not processed. The result of $B a m H I$ digests of the intron containing plasmids is shown in Figure 9. These photographs of an agarose gel demonstrate the various fragment lengths that were inserted. To determine the orientation of the intron insert, each plasmid was digested with $R s a I$, to reveal the unique banding patterns for expressed and reverse orientations, as shown in Figure 10. Once intron containing plasmids were purified and characterized, they were electroporated into carrot and maize protoplasts for analysis of transient CAT activity. Appendix 5 shows corn protoplasts after electroporation.

Transient Assay Results from Carrot Protoplasts

In carrot protoplasts, the insertion of the rbcS intron 1 , with various flanking regions, had an overall negative effect on transient CAT activity, see Figure 11. In fact, due to the nondetectable levels of gene activity in carrot when introns were present in pZO219reverse, pZO210 and pZO210double, the results of those constructs are only presented in Figure 11. The following results pertain to the intron containing plasmids based on pZO219 (CaMV 35S promoter). Introns in the reverse orientation reduced the activity more than the corresponding intron in the expressed orientation. The plasmid containing the largest intron fragment (B1) caused an $86 \%$ drop in activity, compared to control levels (no intron present). Changing the 5 ' flanking region of the intron from $32 \mathrm{bp}$ to $13 \mathrm{bp}$ (comparing B1 to C1) reduced relative activity by another $45 \%$. Further truncation of this region from $13 \mathrm{bp}$ to $3 \mathrm{bp}$ (comparing $\mathrm{C} 1$ to D1) caused another 


\section{RbcS Intron 1 Constructs}

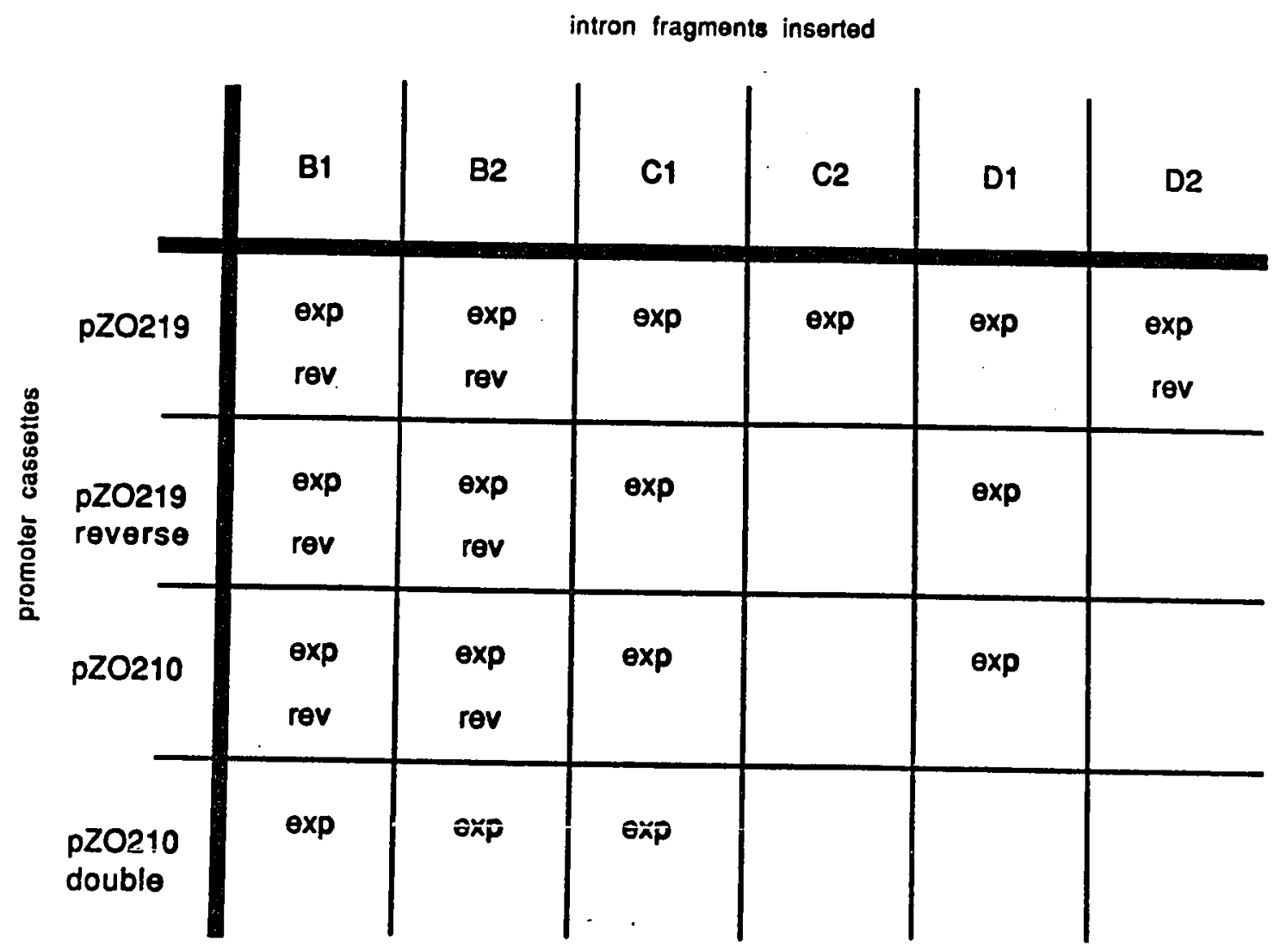

Figure 8. Plasmids isolated and used for electroporation into carrot and maize protoplasts. Orientation of intron insert is indicated by "rev" or "exp". 

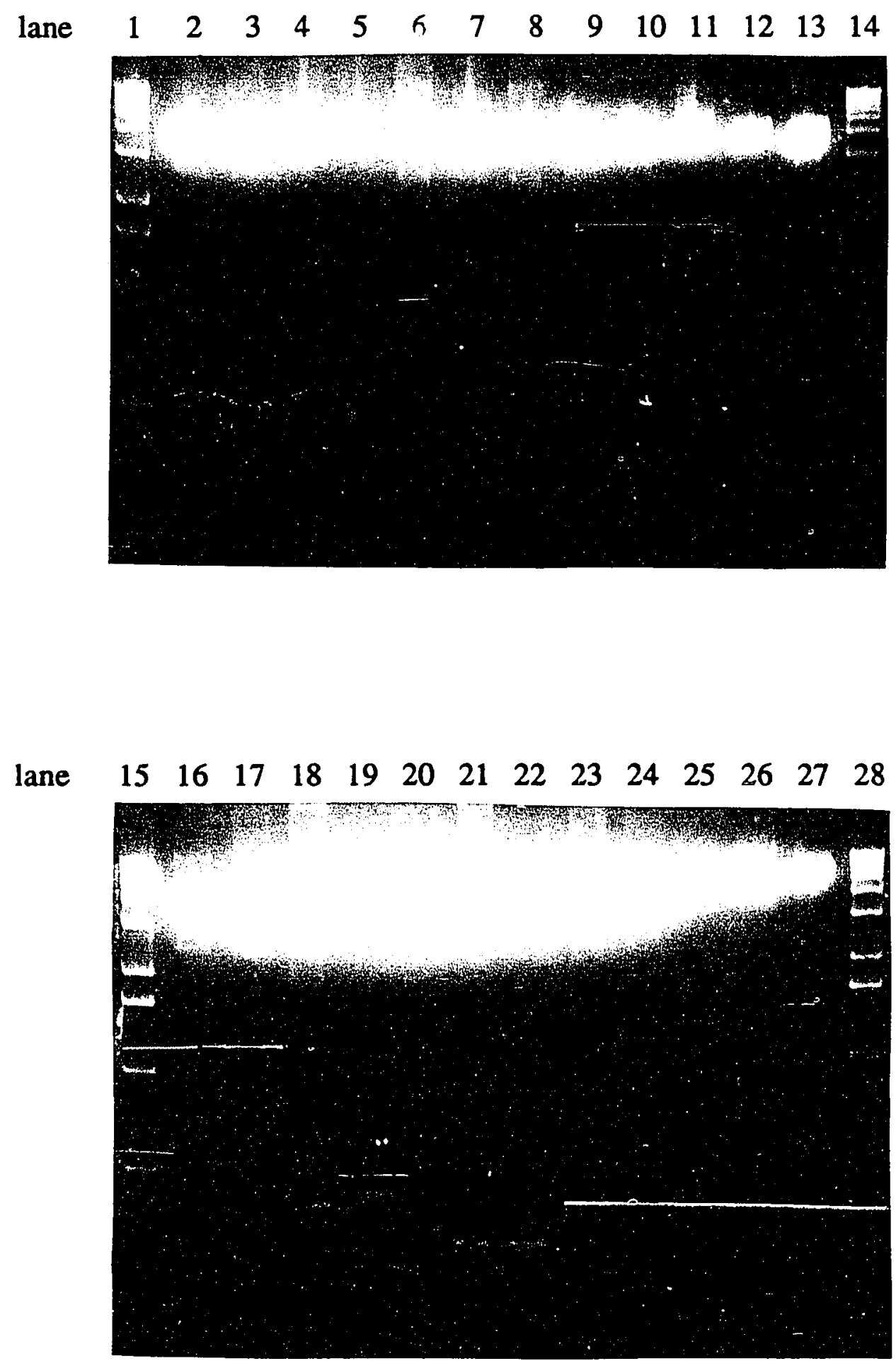
Figure 9. Bam HI digests of $1.5 \mu \mathrm{g}$ intron containing plasmids. Digest shows linear vector of 4187 bp pZO219 and pZO219reverse, 5288 bp pZO210 or 6833 bp pZO210double and a linear intron fragment. Refer to figure 7 for expected size of intron fragments. Gel system was $2 \%$ agarose in $1 \times \mathrm{TAE}$, stained in $1 \mu \mathrm{g} / \mathrm{ml} \mathrm{Et} / \mathrm{Br}$.

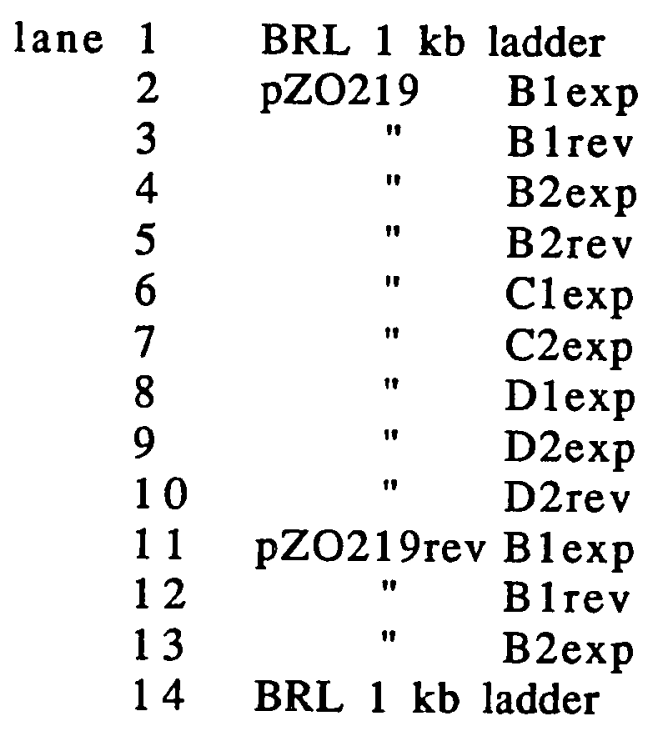

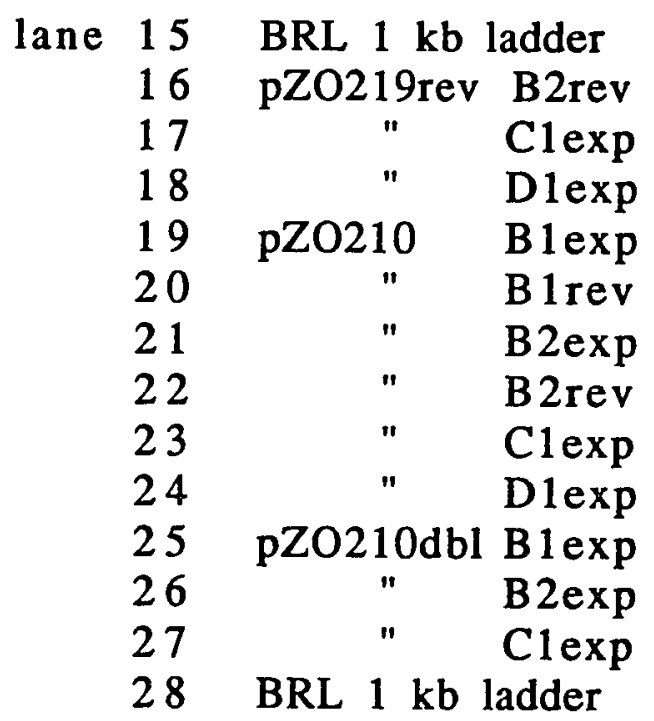

BRL $1 \mathrm{~kb}$ ladder

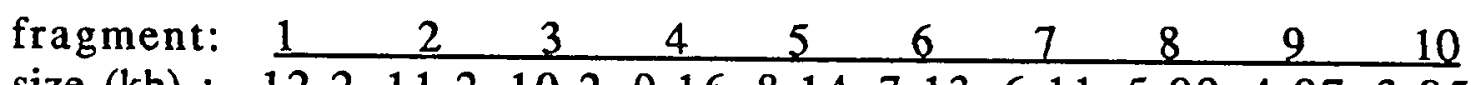
size (kb) : $\begin{array}{lllllllllll}12.2 & 11.2 & 10.2 & 9.16 & 8.14 & 7.13 & 6.11 & 5.09 & 4.07 & 3.05\end{array}$

\begin{tabular}{cccccccccc}
11 & 12 & 13 & 14 & 15 & 16 & 17 & 18 & 19 & 20 \\
\hline 2.04 & 1.64 & 1.02 & 0.52 & 0.51 & 0.39 & 0.34 & 0.29 & 0.22 & 0.20
\end{tabular}

\begin{tabular}{ccc}
21 & 22 & 23 \\
\hline 0.15 & 0.13 & 0.08
\end{tabular}




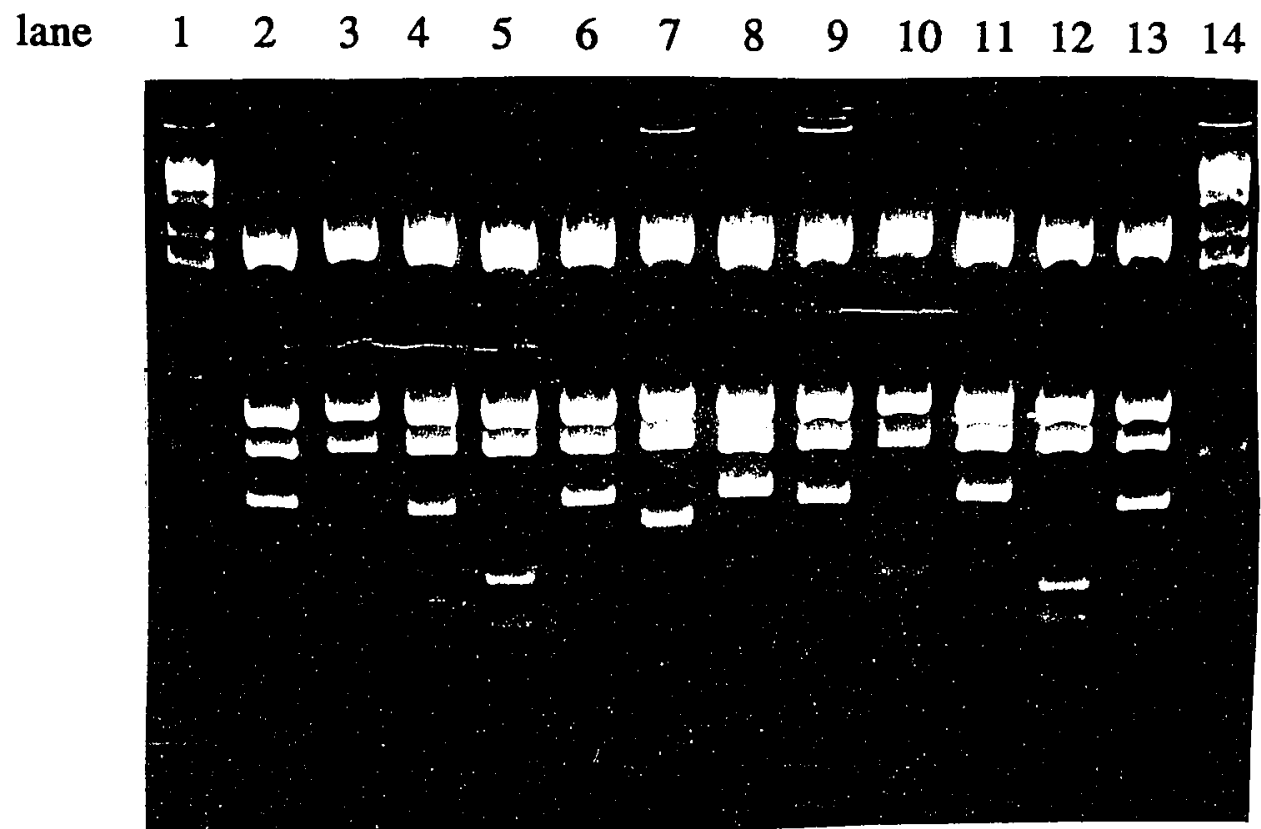

$\begin{array}{lllllllllllllll}\text { lane } & 15 & 16 & 17 & 18 & 19 & 20 & 21 & 22 & 23 & 24 & 25 & 26 & 27 & 28\end{array}$

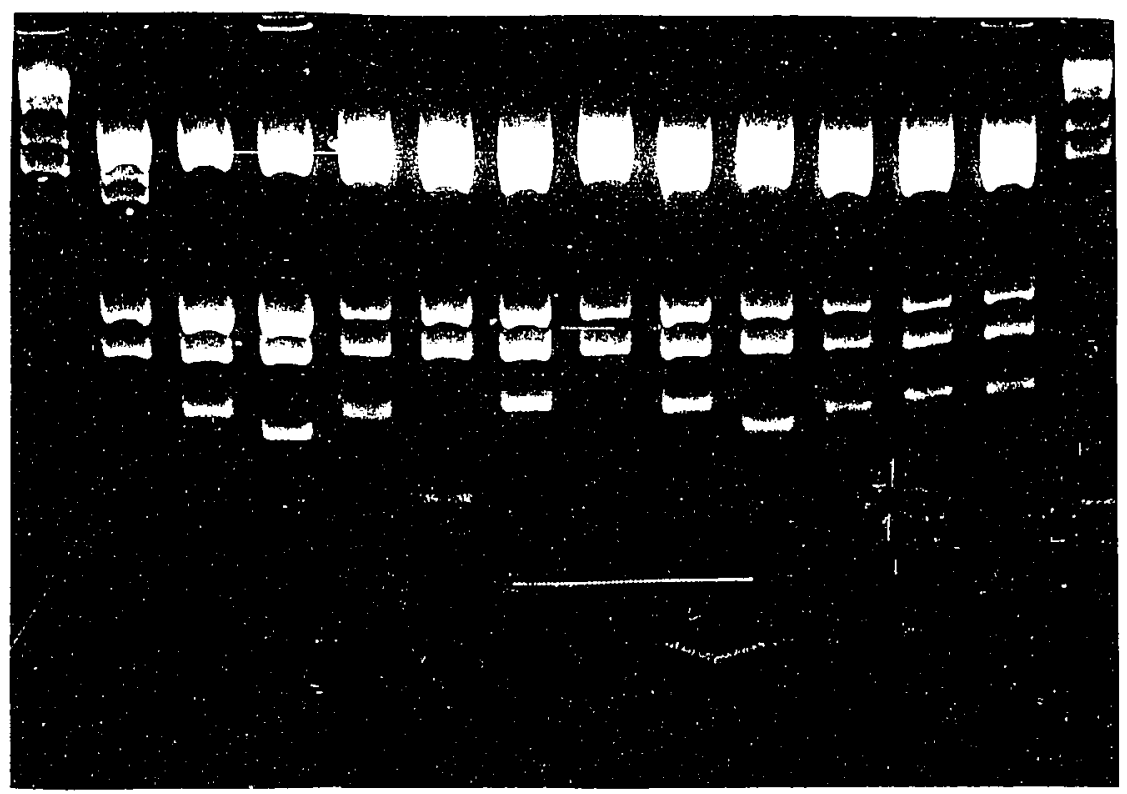


Figure 10. Rsal digests of $1.5 \mu \mathrm{g}$ intron containing plasmids. Digest shows characteristic banding pattern which distinguishes expressed from reverse orientation of the intron fragment. Gel system was $2 \%$ agarose in $1 \times \mathrm{TAE}$, stained in $1 \mu \mathrm{g} / \mathrm{ml} \mathrm{Et} / \mathrm{Br}$.

expected bands from pZO219 and pZO219 reverse, bp/band

expressed

2134

698

663

538

373

26

\section{reverse}

2134

698

663

538

233

166 expected bands from $\mathrm{pZO} 210$ and $\mathrm{pZO} 210 \mathrm{double}, \mathrm{bp} / \mathrm{band}$

$\begin{array}{ll}\text { expressed } & \text { reverse } \\ 2379 & 2379 \\ 1776 & 1776 \\ 663 & 663 \\ 538 & 538 \\ 373 & 233 \\ 26 & 166 \\ 23 & 23\end{array}$

\begin{tabular}{|c|c|c|c|c|}
\hline lane 1 & BRL $1 \mathrm{~kb}$ ladder & lane 15 & BRL $1 \mathrm{~kb}$ & ladder \\
\hline 2 & pZO219 B1 exp & 16 & pZO219rev & B2rev \\
\hline 3 & B1rev & 17 & $"$ & $\mathrm{Cl} \exp$ \\
\hline 4 & B2exp & 18 & $"$ & D1exp \\
\hline 5 & B 2rev & 19 & pZO210 & B $1 \exp$ \\
\hline 6 & Clexp & 20 & $"$ & B 1 rev \\
\hline 7 & C2exp & 21 & $"$ & B2exp \\
\hline 8 & D1exp & 22 & $"$ & B2rev \\
\hline 9 & $D 2 \exp$ & 23 & $"$ & $\mathrm{Clexp}$ \\
\hline 10 & $" \quad$ D2rev & 24 & $"$ & D1exp \\
\hline 11 & pZO219rev Blexp & 25 & pZO210dbl & B 1 exp \\
\hline 12 & " B 1 rev & 26 & " & B2exp \\
\hline 13 & $" \quad$ B2exp & 27 & $"$ & Clexp \\
\hline 14 & BRL $1 \mathrm{~kb}$ ladder & 28 & BRL $1 \mathrm{~kb}$ & ladder \\
\hline
\end{tabular}

BRL $1 \mathrm{~kb}$ ladder (see figure 9 for band sizes) 
Carrot Transient Assay Results

\begin{tabular}{|c|c|c|c|}
\hline Construct & \% Acetylation & Rel. CAT Activity & \# reps \\
\hline pZO219 & $21.3 \pm 21.3$ & 1 & 7 \\
\hline Blexp & $2.2 \pm 2.2$ & $0.144 \pm 0.09$ & 6 \\
\hline B1rev & $0.22 \pm 0.22$ & $0.01 \pm 0.003$ & 3 \\
\hline B2exp & $0.80 \pm 0.71$ & $0.049 \pm 0.03$ & 3 \\
\hline B2rev & $0.12 \pm 0.21$ & $0.004 \pm 0.35$ & 3 \\
\hline Clexp & $1.8 \pm 1.8$ & $0.08 \pm 0.038$ & 3 \\
\hline$C 2 \exp$ & $0.70 \pm 0.68$ & $0.031 \pm 0.015$ & 3 \\
\hline D1exp & $0.77 \pm 0.77$ & $0.028 \pm 0.14$ & 3 \\
\hline D2exp & $0.29 \pm 0.19$ & $0.052 \pm 0.02$ & 3 \\
\hline D2rev & $0.19 \pm 0.19$ & $0.007 \pm 0.007$ & 3 \\
\hline pZO219rev. & $0.37 \pm 0.36$ & $0.003 \pm 0.003$ & 3 \\
\hline B $1 \exp$ & 0 & 0 & 2 \\
\hline Blrev & 0 & 0 & 2 \\
\hline B2exp & 0 & 0 & 2 \\
\hline B2rev & 0 & 0 & 2 \\
\hline Clexp & 0 & 0 & 2 \\
\hline Dlexp & 0 & 0 & 2 \\
\hline pZO210 & $<21.31$ & $<1.0$ & 2 \\
\hline B lexp & 0 & 0 & 2 \\
\hline B1rev & 0 & 0 & 2 \\
\hline B2exp & 0 & 0 & 2 \\
\hline B2rev & 0 & 0 & 2 \\
\hline Clexp & 0 & 0 & 2 \\
\hline Dlexp & 0 & 0 & 2 \\
\hline pZO210Dbl. & $<21.31$ & $<1.0$ & 2 \\
\hline Blexp & 0 & 0 & 2 \\
\hline B2exp & 0 & $\mathbf{0}$ & 2 \\
\hline Clexp & 0 & 0 & 2 \\
\hline
\end{tabular}

Figure 11. Relative CAT activity of constructs electroporated into carrot protoplasts. All activities are relative to the non-intron control, pZO219. \# reps (repetitions) indicates number of protoplasts batches tested. Within each batch of protoplasts the constructs were tested in duplicate. 
$65 \%$ drop in activity. Overall, reducing the $5^{\prime}$ flanking region caused a 97\% drop in CAT activity. Changes in the 3 ' flanking region had different results.

In carrot, increasing the 3 ' flanking exon region from 7 bp to $26 \mathrm{bp}$, (comparing $\mathrm{B} 1$ to $\mathrm{B} 2, \mathrm{C} 1$ to $\mathrm{C} 2$, and D1 to D2 in Figure 11) caused a decrease in relative activity except in the case of the D2 construct. Although its CAT activity is only $5 \%$ of the control activity, it is higher than the comparable D1 constructs activity.

Generally, inserting the variations of the rbcS intron 1 into the 5 untranslated leader of the CAT gene caused a drastic decrease in CAT activity (Figure 12).

Transient Assay Results from Maize Protoplasts

The effect of the rbcS intron variations in maize was quite different from the results in carrot. Instead of causing a decrease in activity, some of the constructs increased the CAT activity, see Figure 13. Introns in the reverse orientation were just as deleterious to CAT activity as they were in carrot.

Insertion of the largest intron fragment (B1exp) into pZO219 caused a nine fold enhancement of CAT activity above control levels, see Figure 14. The constructs with the shorter $5^{\prime}$ exon sequences led to decreases in activity down to control levels, seen in pZO219 Clexp, and then below control levels pZO219 D1exp.

Increasing the $3^{\prime}$ flanking region in maize protoplasts followed the same pattern as carrot CAT activity. In comparable constructs ( $\mathrm{B} 1$ and $\mathrm{B} 2, \mathrm{C} 1$ and $\mathrm{C2}$ ), increasing the 3 ' flanking region from $7 \mathrm{bp}$ to 26 bp caused a decrease in activity. However, in the D2 construct, the CAT activity was enhanced three fold over control levels. This is much greater $\%$ increase in activity than was seen in carrot with this same construct.

Therefore, insertion of the rbcS intron enhanced CAT activity significantly above control levels. Further reductions in the $5^{\prime}$ and $3^{\prime}$ flanking regions did cause a decrease below the enhanced level, 
Relative CAT Activity in Carrot Protoplasts

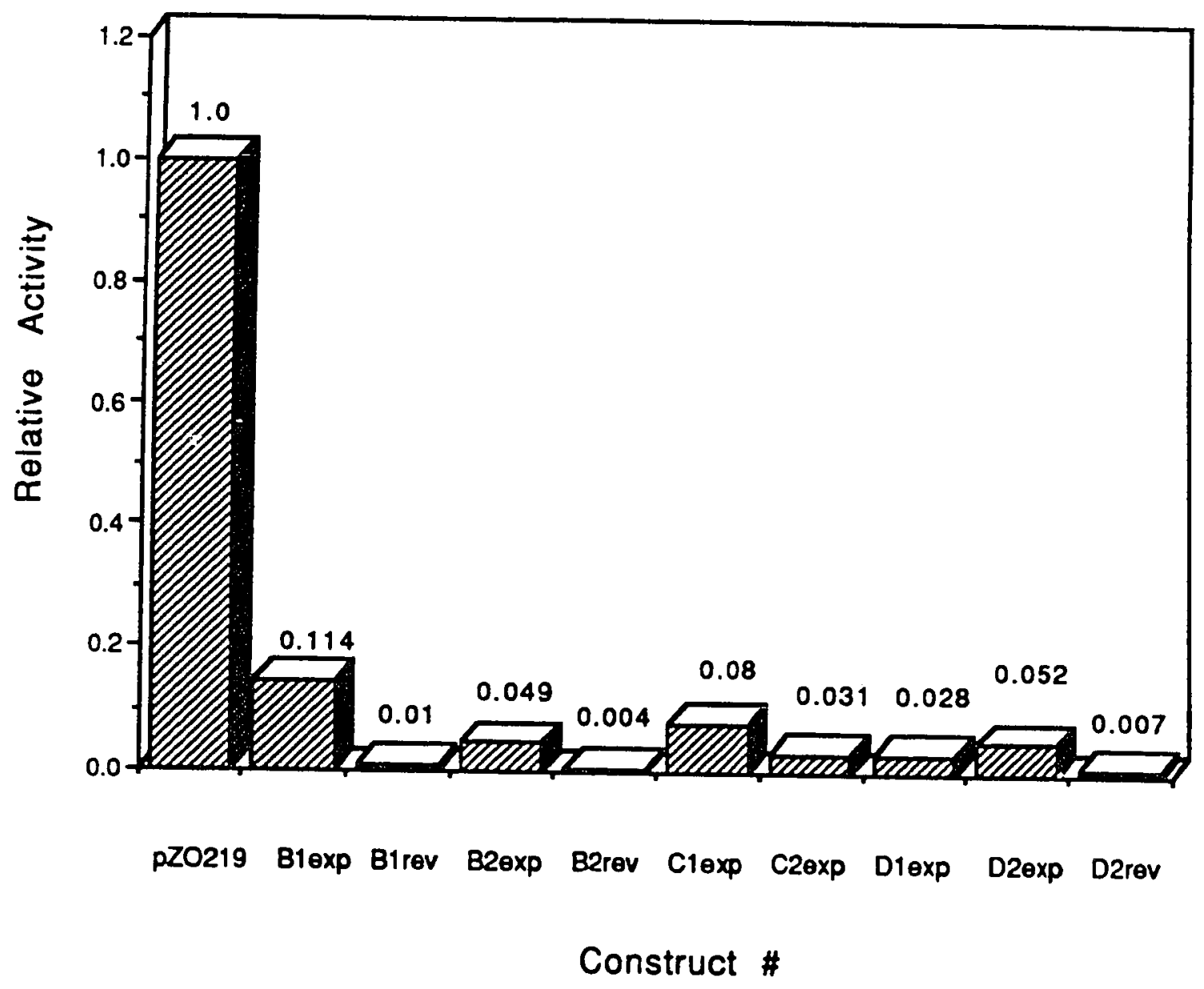

Figure 12. Relative activity of pZO219 and its intron containing derivatives, in carrot. All activities are reported as relative to pZO219. 
Maize Transient Assay Results

Construct \# \% Acetylation Rel. CAT Activity

\# reps

pZO219

B $1 \exp$

$1.85 \pm 1.65$

1.0

3

B1rev

$21.25 \pm 19.95$

$9.29 \pm 0.3$

B2exp

$2.16 \pm 2.14$

$0.65 \pm 0.545$

B2rev

$0.48 \pm 0.05$

$1.8 \pm 0.43$

Clexp

$0.025 \pm 0.05$

$0.07 \pm 0.04$

C2exp

$0.295 \pm 0.015$

$0.836 \pm 0.15$

2

D1exp

$0.195 \pm 0.015$

$0.69 \pm 0.4$

D2exp

$0.025 \pm 0.05$

$0.07 \pm 0.03$

$1.0 \pm 0.27$

$2.9 \pm 0.7$

D2rev

$0.07 \pm 0.05$

$0.127 \pm 0.05$

pZO219 rev.

0

0

2

B 1 exp

0

0

B1 rev

0

0

2

B2 exp

0

0

B2rev

0

0

2

$\mathrm{Clexp}$

0

0

D $1 \exp$

0

0

pZO210

$<1.85$

$<1.0$

2

B $1 \exp$

0

0

2

Blrev

0

2

B2exp

0

B2rev

0

2

C1exp

0

D1exp

0

2

2

2

pZO210Dbl.

$<1.85$

$<1.0$

2

B 1 exp

$0.23 \pm 0.08$

B2exp

0

$0.12 \pm 0.07$

2

0

0

Figure 13. Relative CAT activity of constructs electroporated into maize protoplasts. All activities are relative to the non-intron control, pZO219. \# reps (replicates) indicates the number of protoplast batches tested. Within each batch, duplicate reactions of each construct were done. 


\section{Relative CAT Activity in Corn Protoplasts}

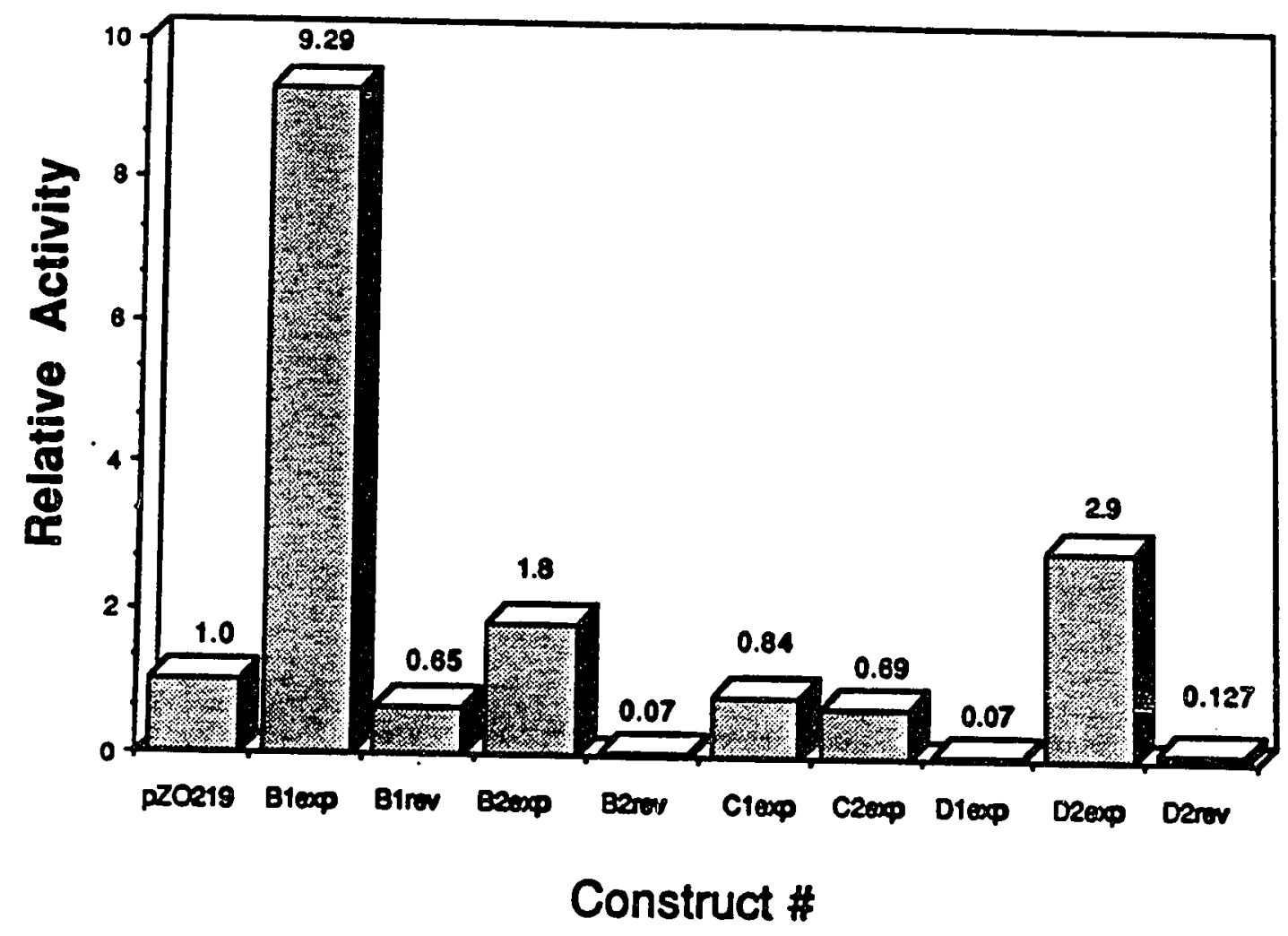

Figure 14. Relative activity of pZO219 and its intron containing derivatives, in maize. All actvities are reported as relative to pZO219. Note enhanced activity with B1 exp, B2 exp and D2 exp intron inserts. 
except in the D2 construct. A similar increase in CAT activity in maize was noted upon addition of a maize Adh 1 intron to DNA cassettes (Callis et al., 1987).

These results are consistent with the observations of other investigators that dicot introns are not processed as efficiently in dicots as they are in monocots. Alternatively, the negative effect on transient gene expression could be due to residual exon sequences still present in the $5^{\prime}$ untranslated region after the splicing of the introns, rather than due to a lack of efficient processing. Preliminary evidence from studies in progress, suggest that maize protoplasts are capable of splicing introns in plasmids similar to the ones used in this study (R. Sinibaldi, personal communication). There is yet no evidence of splicing occurring in carrot protoplasts. 


\section{Discussion}

There are many different factors which could effect the CAT gene expression when an intron is present, as seen in the transient assays in both carrot and maize. All splicing processes occur in the nucleus. Yet, the changes in CAT expression in intron-containing plasmids observed in this study may be due to altered transcription or translation.

One of these factors is the $5^{\prime}$ untranslated leader present in the constucts used for this study. 5' untranslated leader sequences have been shown to stabilize some transcripts by ribosomal interaction (Belasco, 1985) and destabilize others (Piechaczyk et al., 1985; Rabbitts et al., 1985). As presented in this project, if an intron is not spliced out of the transcripts in carrot or maize, the 5' untranslated leader effectively increased from approximately 30 nucleotides (including the multicloning site) to 280 nucleotides. This would increase the distance from the TATA box to the coding sequence of the CAT gene and could result in errors in transcription or errors in translation (interference with ribosome binding), both of which would lead to an overall decrease in detectable CAT activity. The increased leader length could have a positive effect, as well. Constructs containing longer leader sequences have shown greater transient gene activity in maize protoplasts than constructs which had shorter leaders (Pierce et al., 1987; Dietrich et al., 1987). The exact function of these leaders has not been determined. However, 5' untranslated leaders probably do not protect downstream regions of a transcript from RNase activity because RNases usually degrade in the $3^{\prime}-5^{\prime}$ direction, not $5^{\prime}-3^{\prime}$. There is no recognized consensus sequence which represents a "good" leader. However, the length of the leader sequence has been shown to have some effect on transient CAT expression (Pierce et al., 1987; Dietrich et al., 1988). The effect of leader length may not be as important as the actual 
sequence within the leader, as supported by studies on the TMV $\Omega$ leader (Gallie et al., 1988). Because specific sequences may be important, extra sequences introduced during cloning may result in a "bad" leader, thus decreasing gene activity.

Another factor which could change CAT activity is the possible formation of a fusion protein, translated from an in-frame ATG within an unspliced intron or remaining exon sequence and upstream of the true ATG in the CAT gene. The creation of fusions has been used to stabilize some otherwise unstable proteins (Jefferson et al., 1987) and can destabilize others. The addition of amino acids coded by the intron sequence may further stabilize the already relatively stable CAT enzyme. In intron-containing constructs in the expressed orientation with 26 nucleotides of $3^{\prime}$ exon (B2, C2 and D2), there exist two in-frame start codons within the intron and one in-frame start codon in the $5^{\prime}$ exon sequence. The construct containing the D2 intron fragment had only three nucleotides of 5 ' flanking exon and therefore did not contain the exon start codon. However, in this same reading frame, there were four stop codons in the intron and two in the $5^{\prime}$ exon sequence. Thus, constructs containing B2, C2 and D2 intron fragments could not generate fusion proteins whether splicing occured or not. Intron constructs with seven nucleotides of $3^{\prime}$ exon (B1, C1 and D1) contained three in-frame start codons in the intron and one within the $5^{\prime}$ exon sequence. The D1 containing constructs did not have the $5^{\prime}$ exon start codon. Once again, these constructs also contained three stop codons within the intron, although none were present in the $5^{\prime}$ exon. All reverse orientation intron constructs did not contain in-frame start codons and therefore had no chance of forming a fusion protein. Only in the case of $\mathrm{B} 1$ and $\mathrm{C} 1$ expressed orientation constructs was the formation of a fusion protein a possible cause of the changes seen in CAT gene expression.

Therefore, if splicing occurs with $\mathrm{B} 1$ or $\mathrm{Cl}$ constructs, the inframe start codon in the $5^{\prime}$ exon sequence would have no in-frame stop codon prior to the CAT start codon. If splicing occurs and translation starts at that $5^{\prime}$ exon ATG, 23 amino acids would have 
been be added to the 254 amino acid CAT protein. If this happens, we might expect a change in CAT expression from $\mathrm{B} 1$ or $\mathrm{C} 1$ containing constructs. In fact, in both carrot and maize, plasmids containing the $\mathrm{B} 1$ and $\mathrm{Cl}$ intron fragments gave higher activity than the plasmids which contained the corresponding B2 and C2 fragments, in which fusion protein formation is not possible. This activity could be explained if; 1) splicing did not occur, thus leaving intact in-frame stop codons so a deleterious fusion protein was not created, suggesting the increase in activity was due to the $5^{\prime}$ leader, or 2) splicing did occur and a more stable fusion protein was made. The second option could explain what is occurring in maize, where we knew certain introns are removed by splicing and where we observed increased gene activity.

Could secondary structure change CAT gene expression? To examine this possibility, the sequences of the intron fragments were analyzed by a computer program to determine if the intron and flanking exon portion of the pre-mRNA could fold back on itself and base pair within the CAT coding sequence. The secondary structure formed might then interfere with CAT gene expression.

If splicing were possible in a particular protoplast type, it would have occurred by the time the CAT coding sequence was fully transcribed (Beyer and Osheim, 1988). For this reason the flanking $5^{\prime}$ and $3^{\prime}$ exon sequences which would remain after splicing were analyzed. Using the IntelliGenetics version 5.1 Sequence program (aligned by Needleman-Wunsch algorithm; IntelliGenetics, Inc., Mt. View, CA.), it was determined that no region longer than seven consecutive nucleotides within the remaining exon sequences of the cloned mRNA could have base paired with sequences in the CAT gene. Therefore, after splicing, the mRNA probably could not fold onto itself to form stable secondary structures which would interfere with translation of the CAT gene.

If splicing did not occur, secondary structure could also form between the intron itself (not just the residual exon sequences) and the CAT message. Again, using IntelliGenetics, it was determined that 
no more than six consecutive nucleotides (all adenine and thymidine) would be able to base pair between the rbcS intron 1 and the CAT coding sequence. Therefore, there is a very low probability of secondary structure formation and subsequent mRNA stability and/or translational problems. If there were more potential base pairs of secondary structure, this could have represented one mechanism by which the mRNA was stable but translation did not
occur.

Thus far, this discussion has covered topics which could effect CAT protein formation and stability at control points other than the
actual splicing event. It is known that inefficient splicing for 1986). Within can decrease gene expression (Keith and Chua, $3^{\prime}$ splice site. Althoug coding sequence there is an additional cryptic splice sites, the carrot the intron containing clones all had intact $3^{\prime}$ splice sites, the carrot or maize snRNPs may have been interacting
with the cryptic splice with the cryptic splice sequence. This aberrant splicing event would remove approximately 430 nucleotides of the CAT coding region, including the normal translation start codon. Obviously, this would have led to a drastic decrease in the level of detectable CAT enzyme.

Another study showed that clones containing only flanking exon sequences in the $5^{\prime}$ leader (as if the intron had been spliced out)
gave much lower activity than gave much lower activity than related clones which contained the same flanking sequences and the intron (Callis et al., 1987). In constructs similar to the ones used in this study, it has also been shown that mutating the $3^{\prime}$ splice site caused a large decrease in gene expression (Silva et al., 1988). Together these studies suggest that the splice event itself is important for gene expression, not only leader sequences or internal intron sequences. Callis et al. (1987) also demonstrated that an observed increase in CAT expression was the result of an increased amount of mature mRNA in the cytoplasm of protoplasts, not the result of increased translation. It is still not known if the increase in cytoplasmic mRNA was due to increased rate of transcription, increased transport of mRNA to the cytoplasm
or improved stability of mRNA in the protoplast nucleus. 
Hamer et al. (1979a) demonstrated that in mammalian cells, similar "intron dependent" increases in gene expression were not due to increased transcription rate and that unspliced RNA did not accumulate in the nucleus. This suggests that increased gene expression was due to increased stability of the mRNA in the nucleus and subsequent transport into the cytoplasm.

With these different factors in mind, possible explanations for the results of this study are complex. Results in carrot and maize will be discussed separately, keeping in mind the possibility of splicing occurring or not occurring in each protoplast system.

The level of CAT gene expression due to intron containing plasmids in carrot was at least ten-fold lower than non-intron containing control levels. Constructs containing the maize Adh-1 intron have shown similar decreases in gene expression in carrot protoplasts (Silva et al., 1988) and in other dicots, including tobacco (Keith and Chua, 1986) and tomato (J. West, personal communication). Concurrent studies have shown similar results with constructs containing a Brassica heat shock intron, (data not presented).

Carrot protoplasts express introduced genes more efficiently if the $5^{\prime}$ untranslated leader is relatively short (Dietrich et al., 1987). Without an intron, pZO219 has a $5^{\circ}$ untranslated leader of approximately 30 nucleotides and expresses enough CAT to acetylate approximately $30 \%$ of exogenous chloramphenicol. This value represents high expression of the CAT gene. However, upon addition of an rbcS intron fragment, the CAT expression in carrot drops to very low levels (as low as $0.02 \%$ acetylation). If splicing of the intron did not occur, the 5 ' untranslated leader would be increased from the near optimal 30 nucleotides to 250 or more. This increase in leader length may affect the stability of the mRNA transcript or the translational efficiency. If splicing of the constructs occurred in electroporated carrot protoplasts, the leader length would include the 30 nucleotides of polylinker, plus the 5 flanking exon regions, ranging from 10 to 58 nucleotides. Controls used in this 
project and others (Pierce et al., 1987; Dietrich et al., 1987) demonstrate that even such a small increase in leader length can reduce activity in carrot. Therefore, iin carrot protoplasts, the positive effects contributed by a 5 ' untranslated leader to mRNA stability, processing and subsequent gene expression, are negated whether splicing occurs or not. This may be the reason that all dicot species tested with the rbcS intron fragments gave a similar decrease in gene expression. Compared to the effects of the increased leader length if splicing did not occur, the possible effects of fusion protein and secondary structure formation are not as significant. The information gained from this thesis and another study (Keith and Chua, 1988) suggests that the results seen in carrot are due to inefficient processing of the pre-mRNA from monocot and dicot sources. The inefficient splicing in carrot may lead to increases in the $5^{\prime}$ untranslated leader and subsequently, drastic decreases in detectable CAT gene expression.

The insertion of the first rbcS intron into CAT constructs in maize protoplasts led to as much as a ten-fold increase in CAT expression above non-intron control levels. Introns from the above mentioned sources also cause a similar increase in gene activity (Adh-1 and Brassica HS-1). This suggests that the origin of the intron may not be the only important factor, but that correct splicing may be equally important. Correct splicing of the Adoh- 1 intron in maize protoplasts has been reported (Callis et al., 1987; R. Sinibaldi, personal communication).

Assuming that splicing of the rbcS intron occurred, we can essentially disregard the possiblity of secondary structure forming between the exon sequences and the CAT coding sequence. The possible changes in the $5^{\prime}$ untranslated leader sequence does not play as important a role in maize protoplasts as it did in carrot. This is due to the increased transient gene expression in maize protoplasts with constructs which contain longer leader sequences. The leader length would be increased whether splicing occurred or not. If splicing occurred, the $5^{\prime}$ untranslated leader would be increased above the 30 
nucleotides in control plasmids (pZO219), to approximately 40 to 90 nucleotides in intron-containing plasmids. Unspliced transcripts would contain leader sequences up to 290 nucleotides. This increase might partially account for the enhanced gene expression in maize protoplasts, as supported by Dietrich et al. (1987). While the formation of a stable fusion protein may account for some of enhancement seen in pZO219 B1exp and Clexp, it does not account for the unexpected 2.9 fold increase in pZO219 D2exp, which is unable to produce fusions.

Therefore, if we assume splicing occurred in electroporated maize protoplasts, some of the observed increases in gene expression may be due to slight increases in leader length and possible formation of fusion proteins. However, these factors cannot account for all of the enhanced activity. Evidence suggests that the splicing event itself may be responsible for the increase in activity (Callis $e t$ al., 1987; Keith and Chua, 1986).

In the case of maize and carrot, examples of a typical dicot and monocot, the inclusion of introns within the $5^{\prime}$ untranslated leader causes very different results. In all dicots tested, the first intron from the soybean rbcS reduced gene expression to almost nondetectable levels. Although dicot species have just as many introns within coding genes as other species, evidence from other studies and the results of this project suggest that carrot protoplasts may not process introduced introns efficiently. Inefficient processing may negate the unknown positive effects of the splicing process and the leader length, thus reducing gene expression.

In maize, the introduction of constructs that contained certain intron fragments, enhanced the CAT gene expression up to ten-fold. Evidence suggests that maize is capable of splicing several introns. Because various introns also enhance gene expression in maize, we know the internal intron sequence is not the only important factor, but the splice event itself is just as important. 
Since the dicovery of introns just over ten years ago, we have learned a tremendous amount about pre-mRNA splicing and other processing events. Evidence presented in may studies, supported by results in this project, suggest that the splice event itself may enhance expression of certain genes. To determine what component of the series of splicing events contributes to the enhanced expression, many more studies will be necessary. 


\section{Appendix 1.}

Plant 5' splice consensus

$\mathrm{C}_{33}$

$\begin{array}{lllllllll}A_{55} & G_{72} & / & G_{100} & U_{100} & A_{70} & A_{55} & G_{65} & U_{49}\end{array}$ $\mathrm{A}_{33}$

Plant putative branch point consensus

$\begin{array}{lllllll}-5 & -4 & -3 & -2 & -1 & 0 & +1 \\ \mathrm{U} & \mathrm{U} & \mathrm{C} & & & & \\ \mathrm{R} & \mathrm{R} & \mathrm{U} & \mathrm{U} & \mathrm{R} & \mathrm{A} & \mathrm{Y}\end{array}$

Plant $3^{\prime}$ splice site consensus

$Y_{70} Y_{69} Y_{71} Y_{56} Y_{66} Y_{60} Y_{61} Y_{53} Y_{56} Y_{57} Y_{78} R_{70} Y_{94} A_{100} G_{100} / G_{60}$

Appendix 1. Conserved sequence elements from plant pre-mRNA introns. The subscripts denote the frequency of occurrence of the consensus bases at each position, expressed as a percentage. (Brown, 1986). $Y$ denotes a pyrimidine ( $C$ or $T$ ). $R$ denotes a purine ( $A$ or $G$ ). A * denotes much higher frequency. 
Appendix 2.

PREPARATION OF COMPETENT CELLS

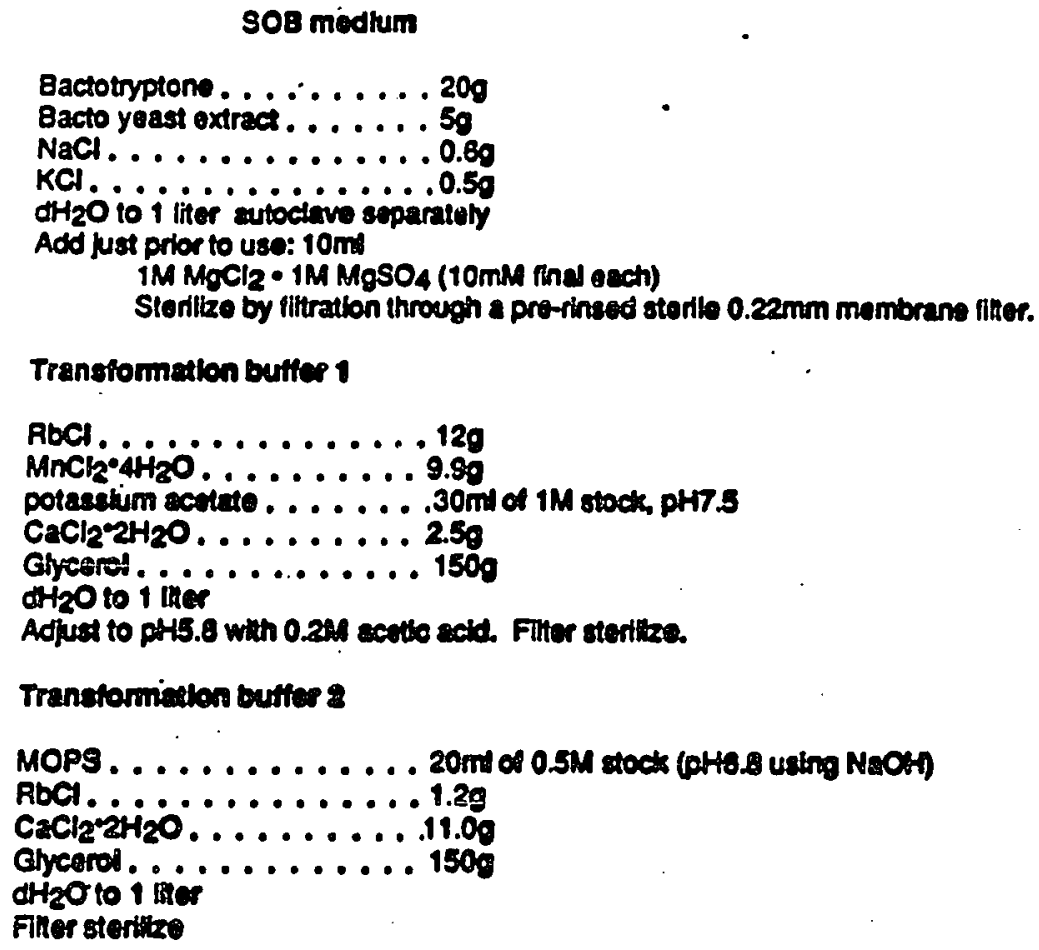

Transtomiaton buffes 8

MOPS . . . . . . . . . . . 20m of 0.5M gtock (PHo. using NaCA)

RbC1................ 1.29

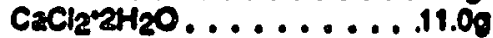

Gycerd............ 1509

dHaOto 1 iner

Finer stertike

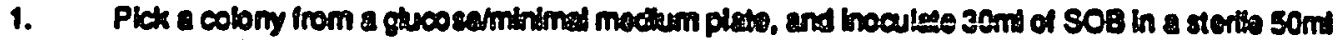
polypropyleno centrituge tubs.

2. Incubate ovemighis at 37C, with moderate aptation

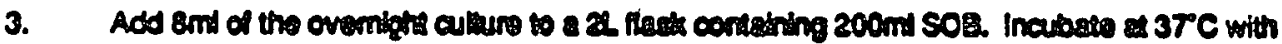
moderate agitation to en 00580 - 0.3,

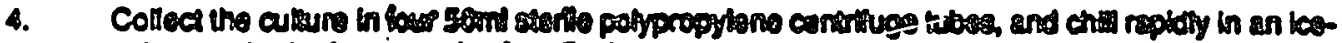
sas-water buth Losvo on los for is mandes

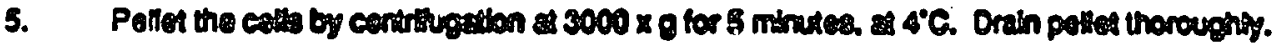

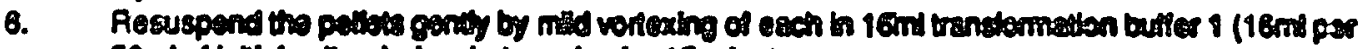

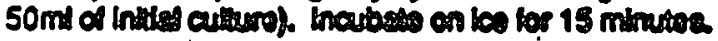

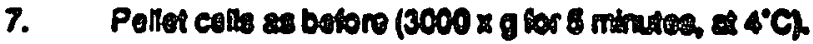

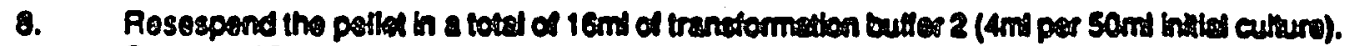
Stors $34^{\circ} \mathrm{C}$ for no more than a few hours balore use

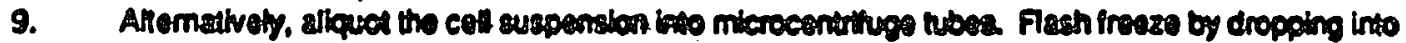

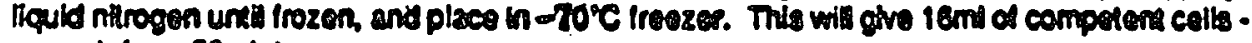
enough for - 50 plates. 
Appendix 3.

Transformation of E. coll

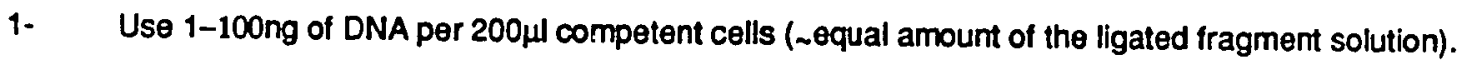

2- Incubate the DNA plus competent cells on ice for $\mathbf{4 0}$ minutes.

3- Heat shock the solution at $42^{\circ} \mathrm{C}$ for 2 minutes (3 minutes when low melt agarose is used).

4- Add 10 fold amount of L-broth $(1 \mathrm{ml})$ and incubate at $37^{\circ} \mathrm{C}$ for 1 hour shaking.

5- Plate out $0.1 \mathrm{ml}$ of the resuspended culture at $1 \mathrm{X}, 0.5 \mathrm{X}$ and $0.01 \mathrm{X}$ onto selective medium plates. 
Appendix 4.

Directions for use of HP1090/HP3396A for CAT activity analysis

Dr. Irv Mettler March, 241988

\section{Set up HPLC/Integrator}

1) check solvent reservoirs; millique water and acetonitrile

2) turn on helium gas, adjust flow as necessary

3) switch power on HPLC - press : [system on] self test will execute

4) set injector size and time - press : [control] [enter] maxinjvolume - 250 [enter]

time- hh $\mathrm{mm}$ ss [enter]

5) load method \#1 - press: [load] [method] 1 [enter]

6) switch pump on - press: [pump on]

7) switch lamp on - press: [lamp on]

8) switch integrator and disc drive power on self test will execute, check paper supply

9) load integrator method: [load] [method] A:CAT [enter] set time and date, type: Date $\mathbf{m m}$ dd yy [enter] Time hh $\mathrm{mm}$ ss [enter]

\section{Test HPLC/Integrator}

10) test for baseline stability, sample separation, printout

a) place CAM standard vial in swing arm holder (\#100)

b) press : [start] $\gg$ (first and last vial) $=100$ (\# of inject.)=2 [enter]

\section{Begin Sequence Run of Samples}

11) flush injector - press : [inj wash] 1 [enter] wash injector for 5 minutes return injector - press : [inj wash] 0 [enter]

12) load vials, check for orientation, center of rack.

13) reset run \# on integrator, type: set runnum 1 [enter]

14) prepare injection sequence (HPLC) - press: [sequence] Enter: meth \#: 1 first vial : $x$ last vial: $y$ \# of inject: 1 [enter] start run : [start] [enter] 

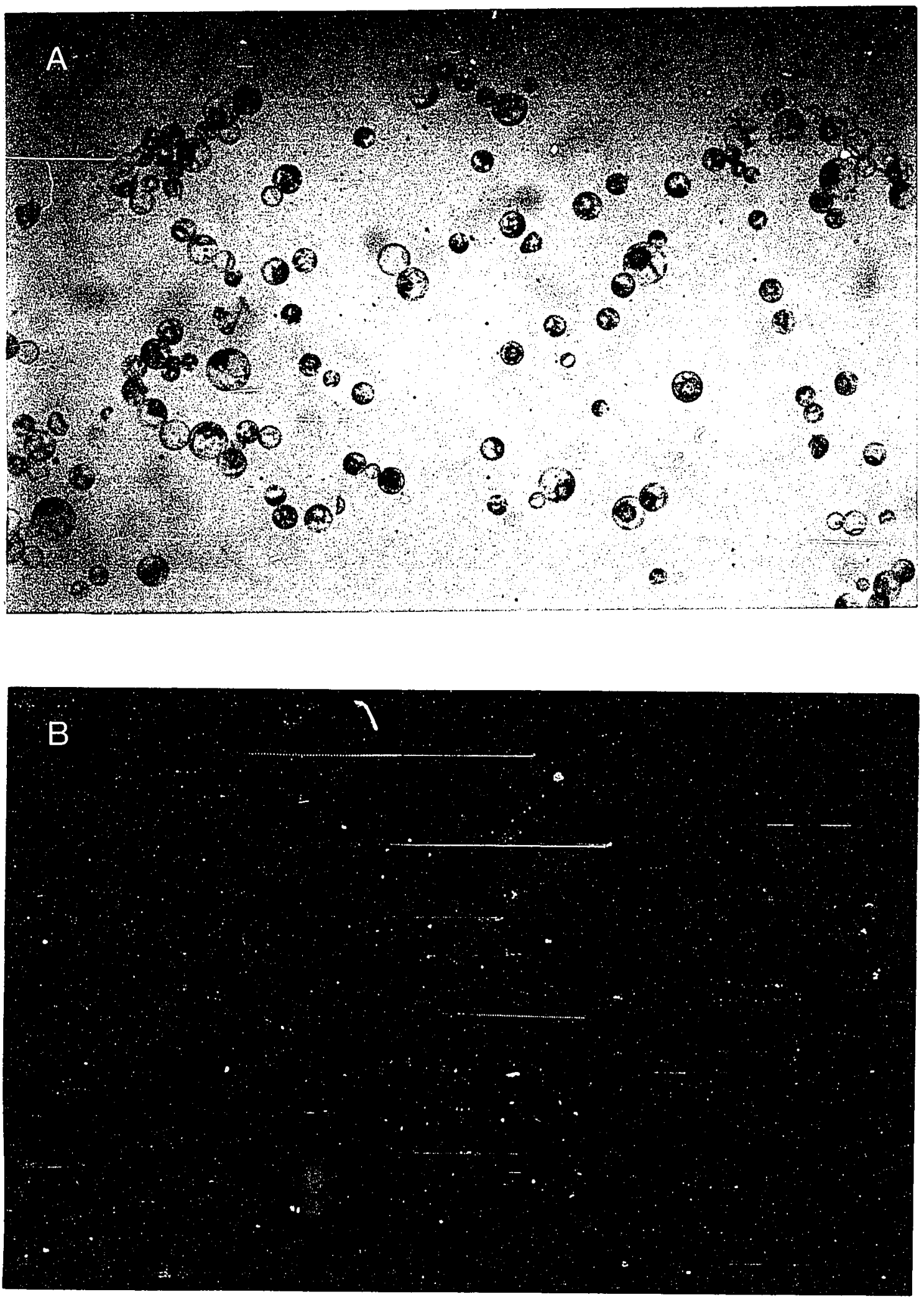


\section{Appendix 5.}

A. Corn protoplasts after introduction of plasmids by electroporation. In protoplasts which are under stress, the cell organelles appear clumped near one side of the cell. The organelles of unstressed protoplasts remain centered within the cell. Stressed protopasts are still functional and will express introduced genes.

B. Corn protoplasts after electroporation and treatment with fluorescein diacetate (FDA). FDA fluoresces when it is cleaved by esterases present in intact cell membranes. Therefore, cells which fluoresce after treatment with FDA have intact cell membranes and are probably viable cells. This is not a quantitative assay for cell activity, but can indicate if a batch of protoplasts has been too damaged for use in CAT assays.

These two photographs do not represent the same concentration of protoplasts. Carrot protoplasts look very similar to corn protoplasts but are slightly larger. 


\section{Literature Cited}

Abelson, J. 1979. RNA processing and the intervening sequence problem. Ann. Rev. Biochem., 48: 1035-1069.

Alfinito, S. C. H., P. S. Dietrich, J. L. Ryals, E. M. Silva, R. M. Sinibaldi, L. E. Murry. 1987. Transient gene expression with different promoters and $3^{\prime}$ polyadenylation sequences in dicot and monocot protoplast systems. J. Cell. Biochem., 11b: 46.

Banerji, J., S. Rusconi, W. Schaffuer. 1981. Expression of a B-globin gene is enhanced by remote SV40 DNA sequences. Cell, 27: 299-308.

Barta, A., K. Sommergruber, D. Thompson, K. Hartmuth, M. A. Motzke, A. J. M. Matzke. 1986. The expression of a nopaline synthase-human growth hormone chimaeric gene in transformed tobacco and sunflower callus. Plant. Mol. Biol., 6: 347-357.

Bates, G. W., J. L. Gaynor, N. S. Shekhawat. 1983. Fusion of plant protoplasts by electric fields. Plant. Physiol., 72: 1110-1113.

Benyajati, C., A. R. Place, N. Wang, E. Pentz, W. Sofer. 1982. Deletions at intervening sequence splice sites in the alcohol dehydrogenase gene of Drosophila. Nucleic Acids Res., 10: 7261-7272.

Berget, S. M., C. Moore, P. A. Sharp. 1977. Spliced segments at the 5' terminus of adenovirus 2 late mRNA. Proc. Natl. Acad. Sci. USA, 74: $3171-3175$.

Berk, A. J. and P. A. Sharp. 1978. Structure of the adenovirus 2 early mRNAs. Cell, 14: 695-711.

Berry-Lowe, S. L., T. D. McKnight, D. M. Shah, R. B.Meagher. 1982. The nucleotide sequence, expression and evolution of one member of a 
multigene family encoding the small subunit of ribulose-1,5bisphosphate carboxylase in soybean. J. of Mol. Appl. Genet., 1: 483498 .

Bertani, G. 1951. Studies on lysogenesis. The mode of phage liberation by lysogenic Escherichia coli . J. Bacteriology, 62: 293-300.

Bevan, M. W., R. B. Flavell, M.-D. Chilton. 1983. A chimaeric antibiotic resistance gene as a selectable marker for plant cell transformation. Nature, 304: 184-187.

Beyer, A. L. and Y. N. Osheim. 1988. Splice site selection, rate of splicing and alternative splicing on nascent transcripts. Genes \& Dev., 2: 754-765.

Bindereif, A. and M. R. Green. 1986. Ribonucleoprotein complex formation during pre-mRNA splicing in vitro.

Mol. Cell. Biol., 6: 2582-2592.

Bingham, P. M., T.-B. Chou, I. Mims, Z. Zachar. 1988.

On/off regulation of gene expression at the level of splicing.

Trends in Genetics, 4: 134-138.

Birnboim, H.C., Doly J. 1979. A rapid alkaline extrastion procedure for screening recombinant plasmid DNA. Nucleic Acids Res., 7: 15131523.

Boggs, R. T., P. Greger, S. Idriss, J. M. Belote, M. McKeown. 1987. Regulation of sexual differentiation in D. melanogaster via alternative splicing of RNA from the transformer gene. Cell, 50: 739-747.

Brinster, R. L., J. M. Allen, R. R. Behringer, R. E. Gelinas, R. D. Palmiter. 1988. Introns increase transcriptional efficiency in transgenic mice. Proc. Natl. Acad. Sci. USA, 85: 836-840. 
Britten, R. J. and E. H. Davidson. 1969. Gene regulation for higher ceilis; Â theory. Ścience, 165: 349-357.

Broglie, R., G. Coruzzi, G. Lamppa, B. Keith, N.-H. Chua. 1983. Structural analysis of nuclear genes coding for the precursor to the small subunit of wheat ribulose-1,5-bisphosphate carboxylase. Bio/Technology, 1: 55-61.

Brown, J.W.S. 1986a. A catologue of splice jurction and putative branch point sequences from plant introns.

Nucleic Acids Res., 14: 9549-9559.

Brown, J.W.S., G. Felix, D. Frendewey. 1986b. Accurate in vitro splicing of two pre-mRNA plant introns in a HeLa cell nuclear extract. EMBO J., 5: 2749-2758.

Buchman, A. R., M. Fromm, P. Berg. 1984. Complex regulation of simian virus 40 early-region transcription from different overlapping promoters. Mol. Cell. Biol., 4: 1900-1914.

Buchman, A. R. and P. Berg. 1988. Comparison of intron-dependent and intron independent gene expression. Mol. Cell. Biol., 8: 43954405 .

Callis, J., M. Fromm, V. Walbot. 1987. Introns increase gene expression in cultured mazie cells. Genes \& Dev., 1: 1183-1200.

Cannon, C., S. Wood, F. Kalish, K. Brunke. 1987. Sequence of a genomic clone for a hsp 81 gene from Brassica oleracea. J. Cell Biology, 105: $246 a$

Cech, T. R., A. J. Zang, P. J. Grabowski. 1981. In vitro splicing of the ribosomal RNA precursor of Tetrahymena; involvement of a 
guanosine nucleotide in the excision of the intervening sequence. Cell,
27: $487-496$.

Cech, T. R. 1983. RNA splicing: Three themes with variations. Cell, 34: 713-716.

Cech, T. R. and B. L. Bass. 1986. Biological Catalysis by RNA. Ann. Rev. Biochem., 55: 599-629.

Chabot, B. and J. A. Steitz. 1987. Multiple interactions between the splicing substrate and small nuclear ribonucleoproteins in spliceosomes. Mol. Cell. Biol., 7: 281-293.

Chang, C. and E. M. Meyerowitz. 1986. Molecular cloning and DNA sequence of the Arabidopsis thaliana alcohol dehydrogenase gene. Proc. Natl. Acad. Sci. USA, 83: 1408-1412.

Chee, P. P., R. A. Klassy, J. L. Slightom. 1986. Expression of a bean storage protein 'phaseolin minigene' in foreign plant tissues. Gene,
$41: 47-57$.

Choi, Y., P. J. Grabowski, P. A. Sharp, G. Dreyfuss. 1986. Heterogenous nuclear ribonucleoproteins: role in RNA splicing.

Science, 231: 1534-1539.

Chou, T. B., Z. Zachar, P. M. Bingham. 1987. Developmental expression of a regulatory gene is programmed at the level of splicing. EMBO J., 6: 4095-4104.

Chow, L. T., R. E. Gelinas, T. R. Broker, R. J. Roberts. 1977. An amazing sequence arrangement at the 5 ' ends of adenovirus 2 messenger RNA. Cell, 12: 1-8. 
Chu, F. K., Maley G. F., Maley F.. 1987. Mechanism and requirements of in vitro RNA splicing of the primary transcript from the T4 bacteriophage thymidylate synthase gene. Biochemistry, 26: 30503057.

Chu, G., H. Hayakawa, P.Berg. 1987. Electroporation for the efficient transîection ố mammalian cells with DNA.

Nucleic Acids Res., 15: 1311-1326.

Darnell, J. E. 1976. mRNA structure and function.

Prog. Nucl. Acids Res. Mol. Biol., 19: 493-511.

Davies, R. W., R. B. Waring, J. A. Ray, T. A. Brown, C. Scazzochio. 1982. Making ends meet: a model for RNA splicing in fungal mitochondria. Nature, 300: 719-724.

Dietrich, G. and V. Walbot. 1988. Regulation of chimeric gene expression in maize protoplasts by intron-1. J. of Cell. Biochem., 12c: 159.

Dietrich, P. S., S. C. H. Alfinito, E. M. Silva, J. L. Ryals, R. M. Sinibaldi, L.E. Murry. 1987. 5' untranslated leader is important for gene expression in electroporated plant protoplasts., J. Cell. Biology, 105: $67 a$.

Doolittle, W. F. 1978. Genes in pieces; were they ever together? Nature, 272: 581-582.

Ecker, J. R., R. W. Davis. 1986. Inhibition of gene expression in plant cells by expression of antisense RNA.

Proc. Natl. Acad. Sci. USA, 83: 5372-5376.

Fang, R.-X., F. Nagy, S. Sivasubramaniam, N.-H. Chua. 1989. Multiple cis regulatory elements for maximal expression of the cauliflower 
mosaic virus $35 \mathrm{~S}$ promoter in transgenic mice. The Plant Cell, 1: 141150.

Fraley, R., S. Subramani, P. Berg, D. Papahadjopoulous. 1980. Introduction of liposome-encapsulated SV40 DNA into cells. J. Biol. Chem., 255: 10431-10435.

Fraley, R. T., R. B. Horsch, A. Matzke, M.-D. Chilton, W. S. Chilton, P. Sanders. 1984. In vitro transformation of petunia cells by an improved method of co-cultivation with A. tumefaciens strains. Plant Mol. Biol., 3: 371-378.

Frendeway, D. and W. Keller. 1985. Stepwise assembly of a premRNA splicing complex requires U-snRNPs and specific intron sequences. Cell, 42: 355-367.

Friedmann, T., A. Esty, P. LaPorte. P. Dieninger. 1979. The nucleotide sequence and genome organization of the polyoma early region: extensive nucleotide and amino acid homology with SV40. Cell, 17: $715-724$.

Fromm, M. and P. Berg. 1983a. Simian virus 40 early- and late-region promoter functins are enhanced by the 72 base-pair repeat inserted at distant locations and inverted orientations. Mol. Cell. Biol., 3: 991999.

Fromm, M. and P. Berg. 1983b. Transcription in vivo from SV40 early promoter deletion mutants without repression by large $\mathrm{T}$ antigen. $\mathrm{J}$. Mol. Appl. Genet., 2: 127-135.

Fromm, M., L. P. Taylor, V. Walbot. 1985. Expression of genes transformed into monocot and dicot plant cells by electroporation. Proc. Natl. Acad. Sci. USA, 82: 5824-5828. 
Gallie, D. R., D. E. Sleat, J. W. Watts, P. C. Turner, T. M. A. Wilson. 1988. Mutational analysis of the tobacco mosaic virus 5'-leader for altered ability to enhance translation. Nucleic Acids Res., 16: 883-893.

Garger, S. J., O. M. Griffith, L. K. Grill. 1983. Rapid purification of plasmid DNA by a single centrifugation in a two-step cesium chloride-ethidium bromide gradient. Biochem. Biophys. Res. Commun., 117: 835-842.

Garriga, G., H. Bertrand, A. M. Lambowitz. 1984. RNA splicing in neurospora mitochondria, nuclear mutants defective in both splicing and $3^{\prime}$ end synthesis of the large RNA. Cell, 36: 623-634.

Ghosh, P. K., V. B. Reddy, J. Swinscoe, P. Lebovitz, S. M. Weissman. 1978. Heterogeneity and 5 terminal structures of the late RNAs of simian virus 40. J. Mol. Biol., 126: 813-846.

Gilbert, W. 1978. Why genes in pieces?. Nature, 271: 501.

Gilbert, W., M. Marchionni, G. McKnight. 1986. On the antiquity of introns. Cell, 46: 151-154.

Gillies, S. D., S. L. Morrison, V. T. Oi, S. Tonegawa. 1983. A tissuespecific transcription enhancer element is located in the major intron of a rearranged imunoglobulin heavy chain gene. Cell, 33: 717-728.

Gorman, C. M., L. F. Moffatt, B. H. Howard. 1982. Recombinant genomes which express chloramphenicol acetyltransferase in mammalian cells. Mol. Cell. Biol., 2: 1044-1051.

Grabowski, P. J., S. R. Seiler, P. A. Sharp. 1985. A multicomponent complex is involved in the splicing of messenger RNA precursors. Cell, 42: 345-353. 
Grabowski, P. J. and P. A. Sharp. 1986. Affinity chromatography of splicing complexes: U2, U5 and U4 + U6 small nuclear ribonucleoprotein particles in the spliceosome. Science, 233: 12941299.

Graessmann, M. and A. Graessmann. 1976. "Early" Simian-Virus-40specific RNA contains information for tumor antigen formation and chromatin replication. Proc. Natl. Acad. Sci. USA, 73: 366-370.

Graham, F. L., A. J. van der Ed. 1973. A new technique for the assay of infectivity of human adenovirus 5 DNA. Virology, 52: 456-467.

Green, M. R. 1986. Pre-mRNA splicing. Ann. Rev. Genet., 20: 671-708.

Greer, C. L. and J. Abelson. 1984. RNA splicing: rearrangement of RNA sequences in the expression of split genes. Trends. Biochem. Sci., 9: 139-141.

Grosschedl, R. and M. L. Birnstiel. 1980. Spacer DNA sequences upstream of the TATAAATA sequence are essential for promotion of H2A histone gene transcription in vivo. Proc. Natl. Acad. Sci. USA, 77: 7102-7106.

Gruss, P., C.-J. Lai, R. Dhar, G. Khoury. 1979. Splicing as a requirement for biogenesis of functional $16 \mathrm{~S}$ mRNA of simian virus 40 . Proc. Natl. Acad. Sci. USA, 76: 4317-4321.

Hamer, D. H., K. D. Smith, S. H. Boyer, P. Leder. 1979a. SV40 recombinants carrying rabbit $B$-globin gene coding sequences. Cell, 17: 725-735.

Hamer, D. H. and P. Leder. 1979b. Splicing and formation of stable RNA. Cell, 18:1299-1302. 
Hauptmann, R. M., P. Ozias-Akins, V. Vasil, Z. Tabaeizadeh, S. G. Rogers, R. B. Horsch, I. K. Vasil. 1987. Transient expression of electroporated DNA in mocotyledonous and dicotyledonous species. Plant Cell Reports, 6: 265-270.

Herrera-Estrella, L., A. Depicker, M. Van Montagu, J. Schell. 1983. Expression of chimaeric genes transferred into plant cells using a Ti plasmid-derived vector. Nature, 303: 209-213.

Howard, B. H. 1983. Vectors for introducing genes into cells of higher eukaryotes. Trends in Biochem., 8: 209-212.

Hozumi, N. and S. Tonegawa. 1976. Evidence for somatic rearrangement of immunoglobulin genes coding for variable and constant regions. Proc. Natl. Acad. Sci. USA, 73: 3628-3632.

Jarrell, K. A., R. C. Dietrich, P. S. Perlman. 1988. Group II intron domain 5 facilitates a trans-splicing reaction. Mol. Cell. Biol., 8: 23612366.

Jefferson, R. A., T. A. Kavanagh, M. W. Bevan. 1987. GUS fusions: Bglucuronidase as a sensitive and versatile gene fusion marker in higher plants. EMBO J., 6: 3901-3907.

Jonak, Z. L., V. Braman, R. H. Kennett. 1984. Production of continuous mouse plasma cell lines by transfection with human leukemia DNA. Hybridoma, 3: 107-118.

Keith, B., N.-H. Chua. 1986. Monocot and dicot pre-mRNAs are processed with different efficiencies in transgenic tobacco. EMBO J., 5: 2419-2425. 
Kiss, T., M. Toth, F. Solymosy. 1985. Plant small nuclear RNAs, nucleolar U3 snRNA is present in plants: partial characterization. Euro. J. Bio., 152: 259-266.

Klein, T. M., E. D. Wolf, R. Wu, J. C. Sanford. 1987. High velocity microprojectiles for delivering nucleic acids into living cells. Nature, 327: 70-73.

Klessig, D. F. 1977. Two adenovirus mRNAs have a common $5^{\prime}$ terminal leader sequence encoded at least $10 \mathrm{~kb}$ upstream of their main coding sequence. Cell, 12: 9-21.

Kruger, K., P. J. Grabowski, A. J. Zang, J. Sands, D. E. Gottschling, T. R. Cech. 1982. Self-splicing RNA: autoexcision and auto-cyclization of the ribosomal RNA intervening sequence of Tetrehymena. Cell, 31:
147-157.

Krol, A. and J. P. Ebel. 1983. U1, U2 and U5 small nuclear RNAs are found in plant cells. Complete nucleotide sequence of the U5 RNA family form pea nuclei. Nucleic Acids Res., 11: 8583-8593.

Kushner, S. R. 1978. An improved method for transformation of Escherichia coli with Col E1-derived plasmids. Genetic Engineering, ed. H. B. Boyer, S. Nicosia, Elsevier/North Holland, Amsterdam. pg.17

Laski, F. A., A. Z. Fire, U. L. RajBhandary, P. A. Sharp. 1983.

Characterization of tRNA precursor splicing in mammalian extracts. J. Biol. Chem., 258: 11974-11980.

Lebrun, M., G. Waksman, G. Freyssinet. 1987. Nucleotide sequence of a gene encoding corn ribulose-1,5-bisphosphate carboxylase/oxygenase small subunit (rbcS). Nucleic Acids Res., 15: 4360 . 
Lerner, M. R., J. A. Boyle, S. M. Mount, S. L. Wolin, J. A. Steitz. 1988. Are snRNPs involved in splicing? Nature, 283: 220-224.

Machy, P., F. Lewis, L. McMillan, Z. L. Jonak. 1988. Gene transfer from targeted liposomes to specific lymphoid cells by electroporation. Proc. Natl. Acad. Sci. USA, 85: 8027-8031.

Maniatis, T., E. F. Fritsch, J. Sambrook. 1982. Molecular cloning (A laboratory manual). Cold Spring Harbor Laboratory.

Manley, J. L., P. A. Sharp, M. L. Gefter. 1979. RNA synthesis in isolated nuclei: in vitro initiation of adenovirus 2 major late mRNA precursor. Proc. Natl. Acad. Sci. USA, 76: 160-164.

Manley, J. L., A. Fire, A. Cano, P. Sharp, M. L. Gefter. 1980. DNAdependent transcription of adenovirus genes in a soluble whole-cell extract. Proc. Natl. Acad. Sci. USA, 77: 3855-3859.

Marchionni, M. and W. Gilbert. 1986. The triosephosphate isomerase gene from maize: introns antedate the plant-animal divergence. Cell, 42:133-141.

McCutchan, J. H. and J. S. Pagano. 1968. Enhancement of the infectivity of simian virus 40 deoxyribonucleic acid with diethylaminoethyl-dextran. J. Natl. Cancer. Inst., 41: 351-357.

Mercola, M., X.-F. Wang, J. Olsen, K. Calame. 1983. Transcriptional enhancer elements in the mouse immunoglobulin heavy chain locus. Science, 221: 663-665.

Michel, F.., A. Jacquier, B. Dujon. 1982. Comparison of fungal mitochondrial introns reveals extensive homologies in RNA secondary structure. Biochemie, 64: 867-881. 
Moreau, P., R. Hen, B. Wasylyk, R. Everett, M. P. Gaub, P. Chambon. 1981. The SV40 72 base repair repeat has a striking effect on gene expression in both SV40 and other chimeric recombinants. Nucleic Acids Res., 9: 6047-6068. Mount, S. M. 1982. A catologue of splice junctions. Nucleic Acids Res.,
10: 459-472.

Mulligan, R. C., B. H. Howard, P. Berg. 1979. Synthesis of rabbit Bglobin in cultures monkey kidney cells following infection with a SV40 B-globin recombinant genome. Nature, 277: 108-114.

Murashige, T. and F. Skoog. 1962. A revised medium for rapid growth and bio assay with tobacco tissue cultures. Physiologia Plantarum, 15: 473-497.

Nagy, F., R. Fluhr, G. Morelli, C. Kuhlemeier, C. Poulsen, B. Keith, M. Boutry, N. H. Chua. 1986. The rubisco small subunit gene as a paradigm for studies on differential gene expression during plant development. Phil. Trans. R. Soc. Lond., 313: 409-417.

Neumann, E., M. Schaefer-Ridder, Y. Wang, P. H. Hofscheider. 1982. Gene transfer into mouse lyoma cells by electroporation in high electric fields. EMBO J., 1: 841-845.

Odell, J. T., F. Nagy, N.-H. Chua. 1985. Identification of DNA sequences required for activity of the cauliflower mosaic virus $35 \mathrm{~S}$ promoter.
Nature, 313: $810-812$.

Odell, J. T., F. Nagy, N.-H. Chua. 1987. Variability in 35 S promoter expression between independent transformants. Plant Gene Systems and their Biology. CIBA-Geigy-UCLA Symposium, 62: 321-329. 
O'Farrell, P. F., C. Weissman. 1981. Replacement synthesis method of labeling DNA fragments. Bethesda Research Labs. Focus, 3: 2-4.

Orgel, L. E., F. H. C. Crick. 1980. Selfish DNA: the ultimate parasite. Nature, 284: 604-607.

Padgett, R. A., S. F. Hardy, P. A. Sharp. 1983. Splicing of adenovirus RNA in a cell-free transcription system. Proc. Natl. Acad. Sci. USA, 80: 5230-5234.

Padgett, R. A., M. M. Konarska, P. J. Grabowski, Stephen F. Hardy, Phillip A. Sharp. 1984. Lariat RNAs as intermediates and products in splicing of messenger RNA precursors. Science, 225: 898-903.

Padgett, R. A., P. J. Grabowski, M. M. Konarska, S. Seiler, P. A. Sharp. 1986. Splicing of messenger RNA precursors. Ann. Rev. Biochem., 55: 1119-1150.

Peebles, C. L., P. Gegenheimer, J. Abelson. 1983. Precise excision of intervening sequences from precursor tRNAs by a membrane associated yeast endonuclease. Cell, 32: 525-536.

Perler, F. and A. Estratiadis. 1980. The evolution of genes: the chicken proinsulin gene. Cell 20: 555-566.

Picard, D., W. Schaffner. 1984. A lymphocyte-specific enhancer in the mouse immunoglobulin $k$ gene. Nature, 307: 80-82.

Piechaczyk, M., J.-Q. Yang, J.-M. Blanchard, P. Jeanteur, K. B. Marai. 1985. Posttranscriptional mechanisms are responsible for accumulation of truncated c-myc RNAs in murine plasma cell tumors. Cell, 42: 589-597. 
Pierce, D. A., I. J. Mettler, A. R. Lachmansingh, L. M. Pomeroy, E. A. Weck, D. Mascerenhas. 1987. Effect of 35S leader modifications on promoter activity. J. Cell. Biochem., suppl. $11 \mathrm{~b}$ : 61 .

Potter, H., L. Weir, P. Leder. 1984. Enhancer-dependent expression of human $k$ immunoglobulin genes introduced into mouse pre- $B$ lymphocytes by electroporation. Proc. Natl. Acad. Sci. USA, 81: 71617165 .

Quigley, F., W. F. Martin, R. Cerff. 1988. Intron conservation across the prokaryote-eukaryote boundary: Structure of the nuclear gene for chloroplast glyceraldehyde-3-phosphate dehydrogenase from maize. Proc. Natl. Acad. Sci. USA, 85: 2672-2676.

Rabbitts, P.H., A. Forester, M.A. Stinson, T.B. Rabbits. 1985. Truncation of exon 1 from c-myc gene results in prolonged c-myc mRNA stability. EMBO J., 4: 3727-3733.

Reed, R. and T. Maniatis. 1988. The role of the mammalian branchpoint sequence in pre-mRNA splicing. Genes \& Dev., 2: 12681276.

Rogers, J. and R. Wall. 1980. A mechanism for RNA splicing. Proc. Natl. Acad. Sci. USA, 77: 1877-1879.

Rogers, John H. 1985. Mechanisms of RNA splicing. Int. Rev. Cytol., 93: 188-231.

Ruskin, B., A. R. Krainer, T. Maniatis, M. R. Green. 1984. Exicision of an intact intron as a novel lariat structure during pre-mRNA splicing. Cell, 38: 317-331.

Schleif, R. F. and P. C. Wensink. 1981. Practical methods in molecular biology. pg 136, 201-202. Springer Verlag, New York. 
Schmeizer, C. and R. J. Schweyen. 1986. Self-splicing of group II introns in vitro : mapping the branch point and mutational inhibition of lariat formation. Cell, 46: 557-565.

Schnuewly S., A. Kuroiwa, P. Baumgartner, W.J. Gehring. 1986. Structural organization and sequence of the homeotic gene Antennapedia of Drosophila melanogaster. EMBO J., 5: 733-739.

Scott, M.P., A.J. Weiner, T.I. Hazelrigg, B.A. Polisky, V. Pirrota, F. Scalenghe, T.C. Kaufman. 1983. The molecular organization of the Antennapedia locus of Drosophila. Cell, 35: 763-766.

Shah, D.M., R.C. Hightower, R.B. Meagher. 1983. Genes encoding actin in higher plants; intron positions are highly conserved but the coding sequences are not. J. Mol. Appl. Genet., 2: 111-126.

Sharp, P. A, B. Sugden, J. Sambrook. 1973. Detection of two restriction endonuclease activities in Haemophilus parainfluenzae using aralytical agarose-ethidium bromide electrophoresis. Biochemistry, 12: $3055-63$.

Shaw, W. V. 1983. Chloramphenicol acetyltransferase: enzymology and molecular biology. CRC Crit. Rev. Biochem., 14: 1-46

Siliciano, P. G. and C. Guthrie. 1988. 5' splice site selection in yeast: genetic alterations in base-pairing with $\mathrm{U} 1$ reveal additional requirements. Genes \& Dev., 2: 1258-1267.

Silva, E. M., I. J. Mettler, P.S. Dietrich, R. M. Sinibaldi. 1988. Enhanced transient expression in maize protoplasts. Genome, 30: pg. 72 (suppl. 1).

Skuzeski, J. M. and J. J. Jendrisak. 1985. A family of wheat embryo U2 snRNAs. Plant Mol. Biol., 4: 181-193. 
Slightom, J. L., S. M. Sun, T. C. Hall. 1983. Complete nucleotide sequence of a French bean storage protein gene: Phaseolin. Proc. Natl. Acad. Sci. USA, 80: 1897-1901.

Spandidos, D. A., M. L. Anderson. 1984. A tissue specific transcription enhancer element in the human immunoglobulin lamba chain locus. FEBS Lett., 175: 152-158.

Sprinzl, M., T. Hartmann, J. Moll, T. Vorderwulbecke. 1987.

Compilation of tRNA sequences and sequences of tRNA genes. Nucleic Acids Res., 15: r53 supplement.

Tao W., J. Wilkinson , E. J. Stanbridge, M. W. Berns. 1987. Direct gene transfer into human cultured cells faciliated by laser micropuncture of the cell membrane. Proc. Natl. Acad. Sci. USA, 84: 4180-4184.

Tartoff, K. D. and C. A. Hobbs. 1987. Improved media for growing plasmids and cosmid clones. Bethesda Research Laboratories Focus, 9: $2-12$.

Tilghman, S. M., D. C. Tiemier, J. G. Seidman, B. Matija Peterlin, M. Sullivan, J. V. Maizel, P. Leder. 1978. Intervening sequence of DNA identified in the structural portion of a mouse B-globin gene. Proc. Natl. Acad. Sci. USA, 75: 725-729.

Tonegawa, S. 1983. Somatic generation of antibody diversity. Nature, 302: 575-581.

Tsukakoshi, M., S. Kurata, Y. Namiya, Y. Ikawa, T. Kasuya. 1984. A novel method of DNA transfection by laser microbeam cell surgery. Appl. Phys. B- Photophysics and laser chemistry, 35: 135-140. 
van der Veen, R., J. H. J. M. Kwakman, L. A. Grivell. 1987. Mutations at the lariat acceptor site allow self-splicing of a group II intron without lariat formation. EMBO J., 6: 3827-3831.

van der Veen, R., A. C. Arnberg, L. A. Grivell. 1987. Self-splicing of a group II intron in yeast mitochondria: dependence on \% exon sequences. EMBO J., 6: 1079-1084.

van der Veen, R., A. C. Arnberg, G. van der Horst, L. Bonen, H. F. Tabak, L. A. Grivell. 1986. Excised group II introns in yeast mitochondria are lariats and can be formed by self-splicing in vitro. Cell, 44: 225-234.

van Santen, V. L., R. Spritz. 1987. Splicing of plant pre-mRNAs in animal systems and vice versa. Gene, 56: 253-265.

Warrant, R. W. and S.-H. Kim. 1978. Alpha helix-double helix interaction shown in the structure of a protamine-transfer RNA complex and a nucleoprotamine model. Nature, 271: 130-135.

Wierbauer, K., J. J. Herrero, W. Filipowicz. 1988. Nuclear pre-mRNA processing in plants: distinct modes of $3^{\prime}$ splice-site selection in plants and animals. Mol. Cell. Biol., 8: 2142-2051.

Wolter, F. P., C. C. Fritz, L. Willmitzer, J. Schell, P. H. Schreier. 1988. rbcS genes in Solanum tuberosum: conservation of transit peptide and exon shuffling during evolution. Proc. Natl. Acad. Sci. USA, 85: 846-850.

Wong, T. K., C. Nicolau, P. H. Hofschneider. 1980. Appearance of betalactamase activity in animal cells upon liposome-mediated geñe transfer. Gene, 10: 87-94. 
Yanish-Perron, C., J. Vierra, J. Messing. 1985. Improved M13 phage cloning vectors and host strains: nucleotide sequences of the M13mp18 and pUC19 vectors. Gene, 33: 103-119.

Young, S. L., A. E. Jackson, D. Puett, M. H. Melner. 1985. Laboratory methods, detection of chloramphenicol acetyltransferase in transfected cells: a rapid and sensitive HPLC-based method. DNA, 4: 469-475.

Zachar, Z., T.-B. Chou, P. M. Bingham. 1987. Evidence that a regulatory gene autoregulates splicing of its transcript. EMBO J., 6: 4105-4111.

Zhuang, Y. and A. M. Weiner. 1986. A compensatory base change in U1 snRNA suppresses 5' splice site mutation. Cell, 46: 827-835.

Zimmerman, U., P. Scheurich. 1981. High frequency fusion of plant protoplasts by electric fields. Planta, 151: 26-32. 